Prepared in cooperation with the

Connecticut Department of Energy and Environmental Protection and New England Interstate Water Pollution Control Commission

\title{
Use of Dissolved Oxygen Monitoring to Evaluate Phosphorus Loading in Connecticut Streams, 2015-18
}

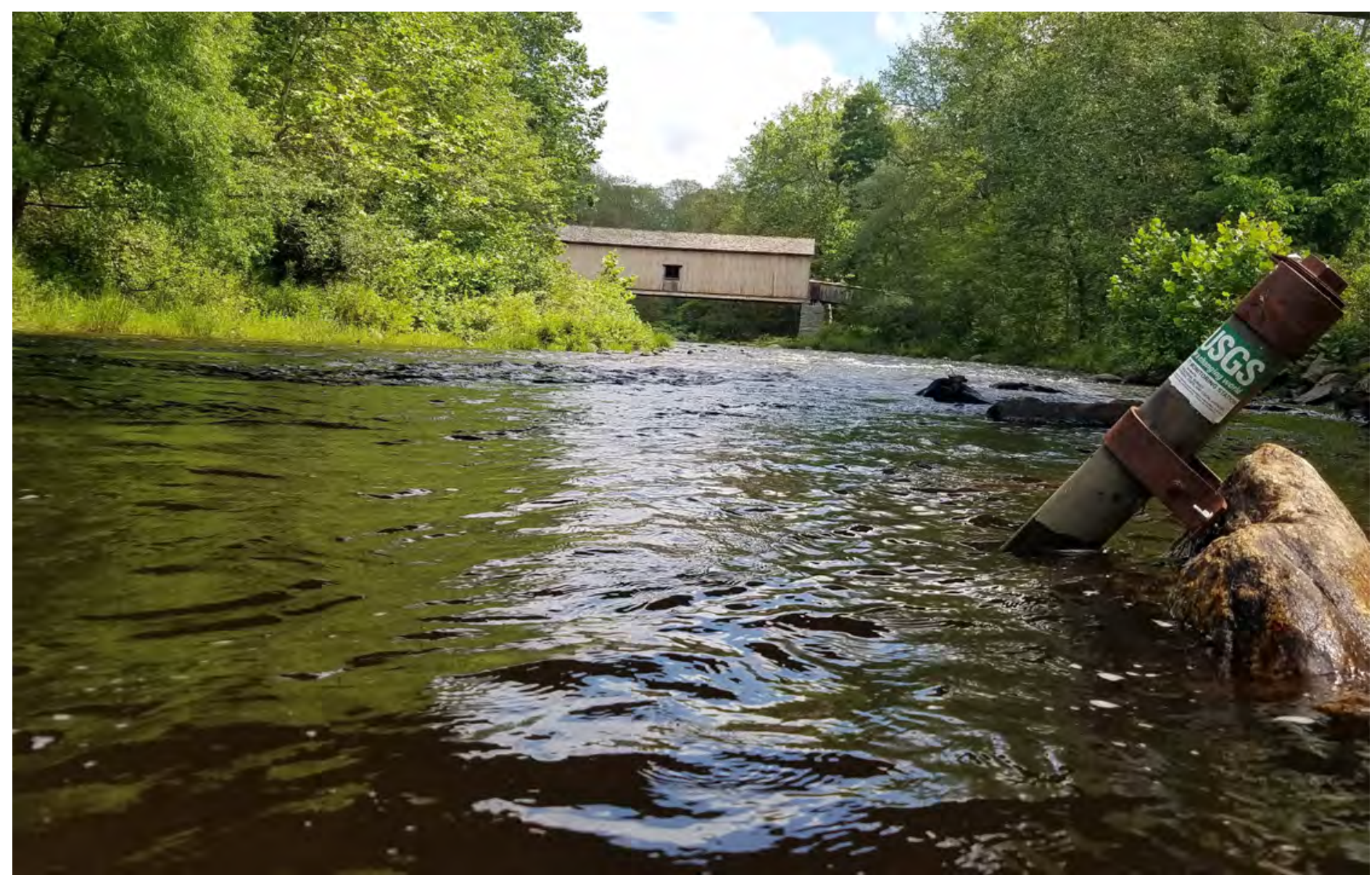

Scientific Investigations Report 2021-5024 
Cover. Photograph showing continuous water-quality monitor taken at Salmon River near East Hampton, Connecticut, on August 3, 2017, by Brittney Izbicki, U.S. Geological Survey. 


\section{Use of Dissolved Oxygen Monitoring to Evaluate Phosphorus Loading in Connecticut Streams, 2015-18}

By Brittney Izbicki and Jonathan Morrison

Prepared in cooperation with the

Connecticut Department of Energy and Environmental Protection and

New England Interstate Water Pollution Control Commission

Scientific Investigations Report 2021-5024 


\section{U.S. Geological Survey, Reston, Virginia: 2021}

For more information on the USGS - the Federal source for science about the Earth, its natural and living resources, natural hazards, and the environment-visit https://www.usgs.gov or call 1-888-ASK-USGS.

For an overview of USGS information products, including maps, imagery, and publications, visit https://store.usgs.gov/.

Any use of trade, firm, or product names is for descriptive purposes only and does not imply endorsement by the U.S. Government.

Although this information product, for the most part, is in the public domain, it also may contain copyrighted materials as noted in the text. Permission to reproduce copyrighted items must be secured from the copyright owner.

Suggested citation:

Izbicki, B., and Morrison, J., 2021, Use of dissolved oxygen monitoring to evaluate phosphorus loading in Connecticut streams, 2015-18: U.S. Geological Survey Scientific Investigations Report 2021-5024, 25 p., https://doi.org/10.3133/ sir20215024.

Associated data for this publication:

Izbicki, B.J., and Morrison, J., 2021, Stream metabolism estimated from dissolved oxygen data in Connecticut streams, 2015-18: U.S. Geological Survey data release, https://doi.org/10.5066/P9HW6IP1.

U.S. Geological Survey, 2020, USGS water data for the Nation: U.S. Geological Survey National Water Information System database, https://doi.org/10.5066/F7P55KJN.

ISSN 2328-0328 (online) 


\section{Acknowledgments}

The authors would like the thank the Connecticut Department of Energy and Environmental Protection and New England Interstate Water Pollution Control Commission. We also would like to thank the following dedicated U.S. Geological Survey employees: Guy Holzer, Michael Colombo, Joseph Martin, Colin Sweeney, Kaitlin Laabs, and Theresa Armijo for data collection, analysis, and approval; John Mullaney for assistance with data processing in streamMetabolizer; and Caroline Mazo for geographic information system mapping. 



\section{Contents}

Acknowledgments ……...................................................................................................................

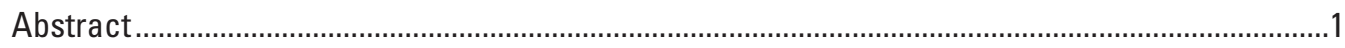

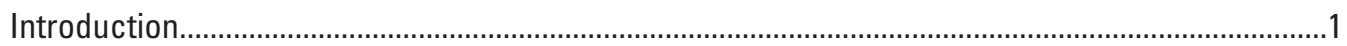

Purpose and Scope ...........................................................................................................

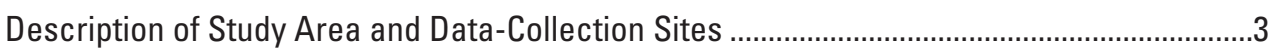

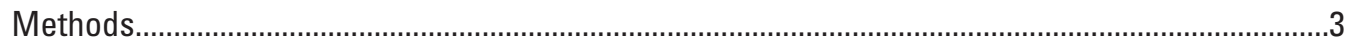

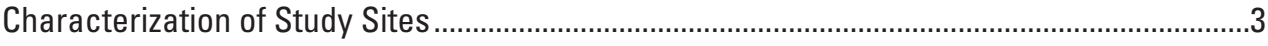

Continuous Monitoring Data Collection and Analysis .................................................................

Discrete Sampling Data Collection and Analysis ......................................................................

Stream Metabolism Computations ....................................................................................

Model Input Variables ............................................................................................

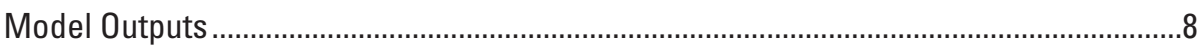

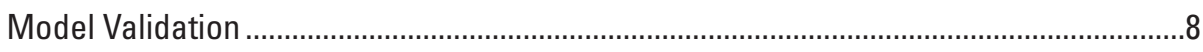

Analysis of Dissolved Oxygen Concentrations ........................................................................

Analysis of Stream Metabolism Outputs ...............................................................................

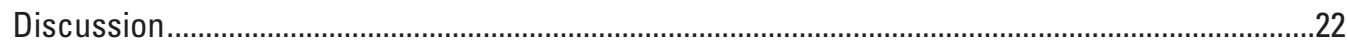

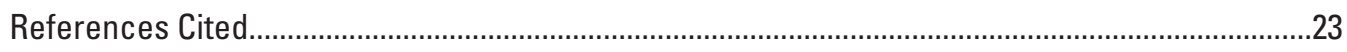

\section{Figures}

1. Map showing monitoring stations for the study, major streams, and drainage basins in Connecticut....................................................................................................

2. Box plots showing daily ranges in study sites in Connecticut across the 4 years..........12

3. Graph showing daily fluctuations of dissolved oxygen and $\mathrm{pH}$ in response to stream metabolism for North Branch Park River at Hartford, Connecticut......................13

4. Box plot showing total phosphorus concentrations at selected sites in Connecticut with discrete sampling during the study for June-September.

5. Scatter plots showing total phosphorus concentrations (in milligrams per liter) against discharge (in cubic feet per second) for selected sites in Connecticut.

6. Graph showing average annual summertime maximum daily dissolved oxygen range and average annual summertime total phosphorus concentrations for study sites in Connecticut for June-September.

7. Scatter plots showing daily estimates of gross primary productivity and ecosystem respiration for each study site in Connecticut and year it was active

8. Scatter plot showing average annual summertime gross primary productivity estimates and average annual summertime total phosphorus concentrations for study sites in Connecticut for June-September

9. Scatter plot showing average annual summertime gross primary productivity estimates (in grams of oxygen per meter squared per day) and average annual summertime maximum daily dissolved oxygen ranges (in milligrams per liter) for study sites in Connecticut for June-September 


\section{Tables}

1. Summary of continuous monitoring, discrete phosphorus sampling, and streamMetabolizer modeling for study sites in Connecticut..

2. Site characterization including the physical and environmental characteristics of study sites in Connecticut...

3. StreamMetabolizer outputs and model diagnostics for study sites in Connecticut .........9

4. Summary of daily dissolved oxygen minimum value, dissolved oxygen maximum value, and maximum daily dissolved oxygen range for every Connecticut site each year it was active.

\section{Conversion Factors}

U.S. customary units to International System of Units

\begin{tabular}{lcl}
\hline \multicolumn{1}{c}{ Multiply } & By & \multicolumn{1}{c}{ To obtain } \\
\hline \multicolumn{3}{c}{ Length } \\
\hline foot $(\mathrm{ft})$ & 0.3048 & meter $(\mathrm{m})$ \\
\hline \multicolumn{2}{c}{ Area } \\
\hline square mile $\left(\mathrm{mi}^{2}\right)$ & 259.0 & hectare $(\mathrm{ha})$ \\
square mile $\left(\mathrm{mi}^{2}\right)$ & 2.590 & square kilometer $\left(\mathrm{km}^{2}\right)$ \\
\hline
\end{tabular}

International System of Units to U.S. customary units

\begin{tabular}{lcc}
\hline \multicolumn{1}{c}{ Multiply } & By & To obtain \\
\hline \multicolumn{3}{c}{ Mass } \\
\hline gram $(\mathrm{g})$ & 0.03527 & ounce, avoirdupois $(\mathrm{oz})$ \\
\hline \multicolumn{3}{c}{ Transmissivity } \\
\hline meter squared per day $\left(\mathrm{m}^{2} / \mathrm{d}\right)$ & 10.76 & foot squared per day $\left(\mathrm{ft}^{2} / \mathrm{d}\right)$ \\
\hline Temperature in degrees Celsius $\left({ }^{\circ} \mathrm{C}\right)$ may be converted to degrees Fahrenheit $\left({ }^{\circ} \mathrm{F}\right)$ as follows: \\
${ }^{\circ} \mathrm{F}=\left(1.8 \times{ }^{\circ} \mathrm{C}\right)+32$.
\end{tabular}

\section{Datum}

Vertical coordinate information is referenced to the North American Vertical Datum of 1988 (NAVD 88).

Horizontal coordinate information is referenced to the North American Datum of 1983 (NAD 83). Altitude, as used in this report, refers to distance above the vertical datum. 


\section{Supplemental Information}

Specific conductance is given in microsiemens per centimeter at 25 degrees Celsius $(\mu \mathrm{S} / \mathrm{cm}$ at $25^{\circ} \mathrm{C}$ ). Concentrations of chemical constituents in water are given in either milligrams per liter (mg/L) or micrograms per liter ( $\mu \mathrm{g} / \mathrm{L})$.

A water year is the period from 0ctober 1 to September 30 and is designated by the year in which it ends; for example, water year 2016 was from October 1, 2015, to September 30, 2016.

\section{Abbreviations}

$\begin{array}{ll}\text { CT DEEP } & \text { Connecticut Department of Energy and Environmental Protection } \\ \text { CV } & \text { coefficient of variation } \\ \text { D0 } & \text { dissolved oxygen } \\ \text { EPA } & \text { U.S. Environmental Protection Agency } \\ \text { ER } & \text { ecosystem respiration } \\ \text { GPP } & \text { gross primary productivity } \\ \text { K600 } & \text { gas exchange rate } \\ \text { MLE } & \text { maximum likelihood estimation } \\ \text { NPDES } & \text { National Pollutant Discharge Elimination System } \\ \text { NPP } & \text { net primary productivity } \\ \text { NWIS } & \text { National Water Information System } \\ \text { PAR } & \text { photosynthetic active radiation } \\ \text { TP } & \text { total phosphorus } \\ \text { USGS } & \text { U.S. Geological Survey }\end{array}$





\title{
Use of Dissolved Oxygen Monitoring to Evaluate Phosphorus Loading in Connecticut Streams, 2015-18
}

\author{
By Brittney Izbicki and Jonathan Morrison
}

\section{Abstract}

The Connecticut Department of Energy and Environmental Protection (CT DEEP) has developed an interim phosphorus reduction strategy to establish waterquality-based phosphorus limits in nontidal freshwaters for industrial and municipal water pollution control facilities. A recommendation in the strategy included the addition of diurnal dissolved oxygen (DO) sampling to the sampling of diatom communities collected by CT DEEP. The chemistry data coupled with biological data will help to examine the effects of phosphorus loading in streams. The U.S. Geological Survey (USGS), in cooperation with the CT DEEP and New England Interstate Water Pollution Control Commission, implemented a summer DO monitoring program from 2015 to 2018 to examine the effects of phosphorus loading in streams. Continuous DO data were collected at 18 sites in streams with varying concentrations of phosphorus throughout the State of Connecticut. Discrete water-quality nutrient data were collected by the USGS at 11 of the 18 sites. All continuous and discrete data collected from June to September for the 4 years were examined for all sites. This report documents a pattern of diurnal DO for monitoring sites across 4 years and presents estimated daily gross primary productivity (GPP), ecosystem respiration (ER), and a standardized rate coefficient for gas exchange for selected streams. Relations of phosphorus concentrations to the diurnal DO response and stream metabolism are described. Interannual variability in average annual total phosphorus (TP) concentrations and maximum daily DO concentrations were evaluated among sites in years of the study. Streams identified as impaired by CT DEEP such as Naugatuck River at Beacon Falls (USGS station 01208500), Still River at Route 7 at Brookfield Center (USGS station 01201487), and Quinnipiac River at Wallingford (USGS station 01196500) had higher TP concentrations (greater than 0.10 milligram per liter $[\mathrm{mg} / \mathrm{L}])$ throughout the study. Reference streams considered unimpaired had lower concentrations of TP (less than $0.10 \mathrm{mg} / \mathrm{L}$ ). The range in daily DO concentrations remained less than $4 \mathrm{mg} / \mathrm{L}$ for most of the sites during the study except for Naugatuck River at Beacon Falls and Still River at Route 7 at Brookfield Center. Daily GPP and ER were summarized for 11 sites using the maximum likelihood estimation model of the streamMetabolizer package in the R statistical program. The models indicated that most sites had an estimated negative net primary productivity, based on the daily estimates of GPP and ER, which indicates the systems are heterotrophic and dominated by respiration. The high variation of GPP and ER reported for several sites can be affected by many physical, chemical, and biological factors, including the abundance and community composition of phytoplankton, periphyton, and macrophyte algae present. The variability in mean GPP was similar to the variability in maximum DO concentrations when plotted against annual average TP concentrations for the maximum likelihood estimation model in streamMetabolizer. The concept that phosphorus loading can affect the stream metabolism requires more detailed knowledge of stream geomorphic variables (canopy cover, stream velocity, water depth) and algal communities to help improve the scientific basis for managing phosphorus loading.

\section{Introduction}

Excessive inputs of phosphorus, driven by point and nonpoint sources, alter the structure and chemistry of inland waters, which can threaten the stream ecosystems (Carpenter and others, 1998; Correll, 1998). The State of Connecticut has many streams that are affected by phosphorus loading from municipal wastewater treatment facilities and nonpoint source runoff. Nutrient enrichment in streams and rivers can increase biomass of aquatic plants and algae, which not only alters the habitat but affects dissolved oxygen (DO) concentrations (Frankforter and others, 2010). Studies on nutrient enrichment in streams have focused on factors such as algal and plant biomass and nutrient concentrations as indicators of nutrient enrichment, but developing predictive models can be difficult because there are many other biological and physical aspects to consider (Dodds and Welch, 2000). Continuous water-quality data provide information on the physical and chemical factors that play major roles in many aspects of stream ecosystems and can provide valuable data for assessing the nutrient enrichment of streams. Evaluation of primary production, from direct measurements of daily diurnal changes in DO (Odum, 1956), can improve the understanding of the effects of excess nutrient loading in streams, which can be 
useful towards the improvement and development of nutrient management (Dodds and Welch, 2000; U.S. Environmental Protection Agency, 2000).

DO is a measure of how much oxygen is dissolved in the water - the amount of oxygen available to living aquatic organisms (Rounds and others, 2013). Odum (1956) introduced a method that uses diurnal (24 hours) trends in DO to measure whole-system metabolism. The diurnal DO concentrations observed in the streams are driven by metabolic rates of gross primary productivity (GPP) and ecosystem respiration (ER). GPP is the rate of formation of organic matter from inorganic sources of carbon through photosynthesis, producing oxygen. ER converts organic carbon to carbon dioxide, consuming oxygen. GPP and ER are estimated by measuring changes in oxygen concentration over time and can indicate total biotic activity (Riley and Dodds, 2013). Net primary productivity (NPP) is the amount of energy stored from metabolic activity in streams (NPP = GPP + ER). NPP is positive when the GPP is greater than the ER and negative when the GPP is less than the ER. Estimated positive NPP indicates that ecosystems are exporting organic carbon, and negative NPP indicates stream ecosystems must be importing organic carbon (Fisher and Likens, 1973).

Methods have been developed to measure trophic state of stream ecosystems by measuring whole-stream metabolism. Trophic state is the attribute of energy availability to the food web and is linked to biotic integrity and water quality of streams. Autotrophic systems convert inorganic carbon to organic carbon for metabolism and growth using energy from light. Heterotrophic systems consume carbon for metabolism and growth from organic carbon (Dodds, 2007). GPP and ER can be used to classify heterotrophic and autotrophic states in rivers (Odum, 1956).

The Connecticut Department of Energy and Environmental Protection (CT DEEP) has been actively involved in developing a phosphorus reduction strategy for inland nontidal waters. In 2012, the Connecticut Legislature passed Public Act 12-155, which directs the chief elected officials of the cities of Danbury, Meriden, and Waterbury; the towns of Cheshire, Southington, and Wallingford; and any other municipalities affected by the statewide strategy to evaluate and make recommendations regarding a statewide approach to reduce phosphorus loading in inland nontidal waters. These recommendations must comply with standards established by the U.S. Environmental Protection Agency (EPA). Section 1 of this act states: "Such evaluation and recommendation shall include: (1) a statewide response to address phosphorus nonpoint source pollution, (2) approaches for municipalities to use in order to comply with standards established by the United States Environmental Protection Agency for phosphorus, including guidance for treatment and potential plant upgrades, and (3) the proper scientific methods by which to measure current phosphorus levels in inland nontidal waters and to make future projections of phosphorus levels in such waters (Public Act 12-155, 2012).” As part of this legislation, the Connecticut Academy of Science and Engineering recommended that future monitoring by CT DEEP include (a) the collection of diurnal DO measurements in addition to CT DEEP's sampling of diatom communities and (b) use of the "stressor response model," which links a stressor such as phosphorus pollution to the ecological state of a stream. Using a single numeric standard in some systems can be difficult (Stressor Response Model; Connecticut Academy of Science and Engineering, 2014). Setting appropriate standards for limiting the amount of phosphorus discharged in a stream can be difficult because of factors that can affect the degree of impact from phosphorus on a stream or river. When mitigating the effect of phosphorus loading, selecting response parameters such as diurnal DO concentrations can measure the effects most directly (Connecticut Academy of Science and Engineering, 2014).

CT DEEP has been evaluating diatom data they have collected in conjunction with phosphorus concentrations and DO data collected by the U.S. Geological Survey (USGS) to help evaluate response parameters and strengthen the approach for determining a concentration-based nutrient criterion in streams (Becker, 2014; Connecticut Academy of Science and Engineering, 2014). Diatom and DO measurements are cost effective, can integrate changes in nutrient concentrations over time, and are important measures of biotic integrity. Because of their strong correlation to phosphorus impairment, it has been recommended that these two parameters be used by Connecticut as the "response parameters" in establishing phosphorus impairment and developing numeric criteria for phosphorus (Connecticut Academy of Science and Engineering, 2014).

The USGS, in cooperation with the CT DEEP and New England Interstate Water Pollution Control Commission, implemented a summer DO monitoring program from 2015 to 2018 to examine the effects of phosphorus loading on stream metabolism, using DO as an indicator of primary productivity and biological response to streams. Continuous DO data were collected at 18 sites on streams with varying concentrations of phosphorus throughout the State of Connecticut. Direct DO measurements from continuous data collection allow for the modeling of stream metabolism and provide a better understanding of the functionality of stream ecosystems (Bales and Nardi, 2007). Data collected for the present study were used to document a pattern of diurnal DO for monitoring sites across 4 years during the summertime; to estimate GPP, ER, and a standardized rate coefficient for gas exchange (K600) for selected streams; and to evaluate the relation among phosphorus concentrations, diurnal DO response, and stream metabolism. This analysis, along with the physical, chemical, and biological data that were compiled (by USGS and CT DEEP) will be beneficial for determining the appropriate phosphorus reductions and for setting targets for waste load allocations and nonpoint source reductions required to meet Connecticut water-quality standards. 


\section{Purpose and Scope}

This report provides information on continuous DO concentrations and phosphorous concentrations during the summer months of 2015-18 at 18 stream sites in the State of Connecticut. The diurnal daily DO data and discrete total phosphorus (TP) data are documented and summarized for all sites throughout the 4-year study. In addition, the report provides estimated daily mean rates of GPP, ER, and K600 for select sites determined using the streamMetabolizer package. The information in this report is intended to provide and summarize data that will be used by CT DEEP to help evaluate the effects of phosphorus loading in Connecticut streams.

\section{Description of Study Area and Data-Collection Sites}

The study sites included 12 streams identified by the CT DEEP as priority sites for DO monitoring that were either impaired by phosphorus or were reference stations generally unimpaired by phosphorus, based on section 303(d) of the Clean Water Act (CT DEEP, 2015). An additional 6 streams were monitored by the USGS for other studies, such as the Northeast Regional Stream Quality Assessment (Van Metre and others, 2016), which totaled 18 study sites throughout Connecticut (fig. 1). The drainage area of the study sites ranged from 21 to 1,022 square miles $\left(\mathrm{mi}^{2}\right)$ and land use ranged from forested to high intensity development. Data were collected during the months of June-September from 2015 to 2018 at the CT DEEP priority sites, April-September 2016 at the Northeast Stream Quality Assessment sites, and during the entire 2016-2018 water year for North Branch Park River at Hartford (USGS station 01191000). Of the 18 sites, 11 also had discrete water-quality samples for nutrients (various forms of phosphorus and nitrogen) collected by the USGS. All continuous and discrete data collection from June to September were evaluated for all sites in the report (fig. 1).

\section{Methods}

A combination of continuous and discrete water-quality data was collected by the USGS. All data are available through the USGS National Water Information System (NWIS) database (U.S. Geological Survey, 2020). Continuous monitoring and discrete phosphorus samples for each site are summarized in table 1. Estimates of GPP, ER, and K600 were obtained using the maximum likelihood estimation (MLE) model with the streamMetabolizer package in the R statistical program (Appling and others, 2017) at 11 sites.

\section{Characterization of Study Sites}

The sites were characterized by factors needed to provide inputs required for streamMetabolizer and to obtain a general understanding of the habitat and stream dynamics (table 2). Lotic systems with low gradients were visually identified. Most of the sites were wadable at normal flows, except for Housatonic River near New Milford (USGS station 01200600) and Quinnipiac River near Meriden (USGS station 01196222). Average depth is a required input variable for streamMetabolizer and was measured at the monitoring location when possible. General characteristics such as width, dominant land use, canopy cover, velocity, and number of upstream wastewater treatment plants were summarized to help provide context for interpreting the metabolism estimates. Velocity was directly measured near the monitoring location at base flow conditions during the summer. The locations of National Pollutant Discharge Elimination System (NPDES) facilities that discharge phosphorus into receiving waters were identified using the municipal facilities geographic information system layer provided by the EPA Discharge Monitoring Report (https://echo.epa.gov/tools/data-downloads/icis-npdesdmr-and-limit-data-set). The dominant land use for each site was characterized using the land use geographic information system layer provided by National Land Cover Database 2011 (https://www.mrlc.gov/data/legends/national-land-coverdatabase-2011-nlcd2011-legend). Canopy cover was measured using a densiometer at the center of the stream near the monitoring location using modified methods from Fitzpatrick and others (1998).

\section{Continuous Monitoring Data Collection and Analysis}

Multiparameter water-quality monitors were deployed from June to September from 2015 to 2018. Each monitor provided continuous 15 -minute measurements of $\mathrm{DO}$, water temperature, specific conductance, and $\mathrm{pH}$. Most monitors were deployed to log data internally, and data were downloaded during site visits. Some sites had real-time existing monitors. All data are available through the USGS NWIS database (https://waterdata.usgs.gov/ct/nwis/qw). Monitor maintenance and data reporting followed standard procedures defined in Wagner and others (2006).

Cross sections were completed at every site during the deployment each year to ensure that the monitor locations were representative of the streams. Cross sections consisted of five section measurements recorded middepth in the streams and measured water temperature, specific conductance, DO, and $\mathrm{pH}$. All monitors were checked for accuracy and function in the laboratory-controlled environment, and water temperature thermistors were checked to ensure they passed five-point temperature checks against a National Institute of Standards and Technology certified laboratory thermometer before deployment. 


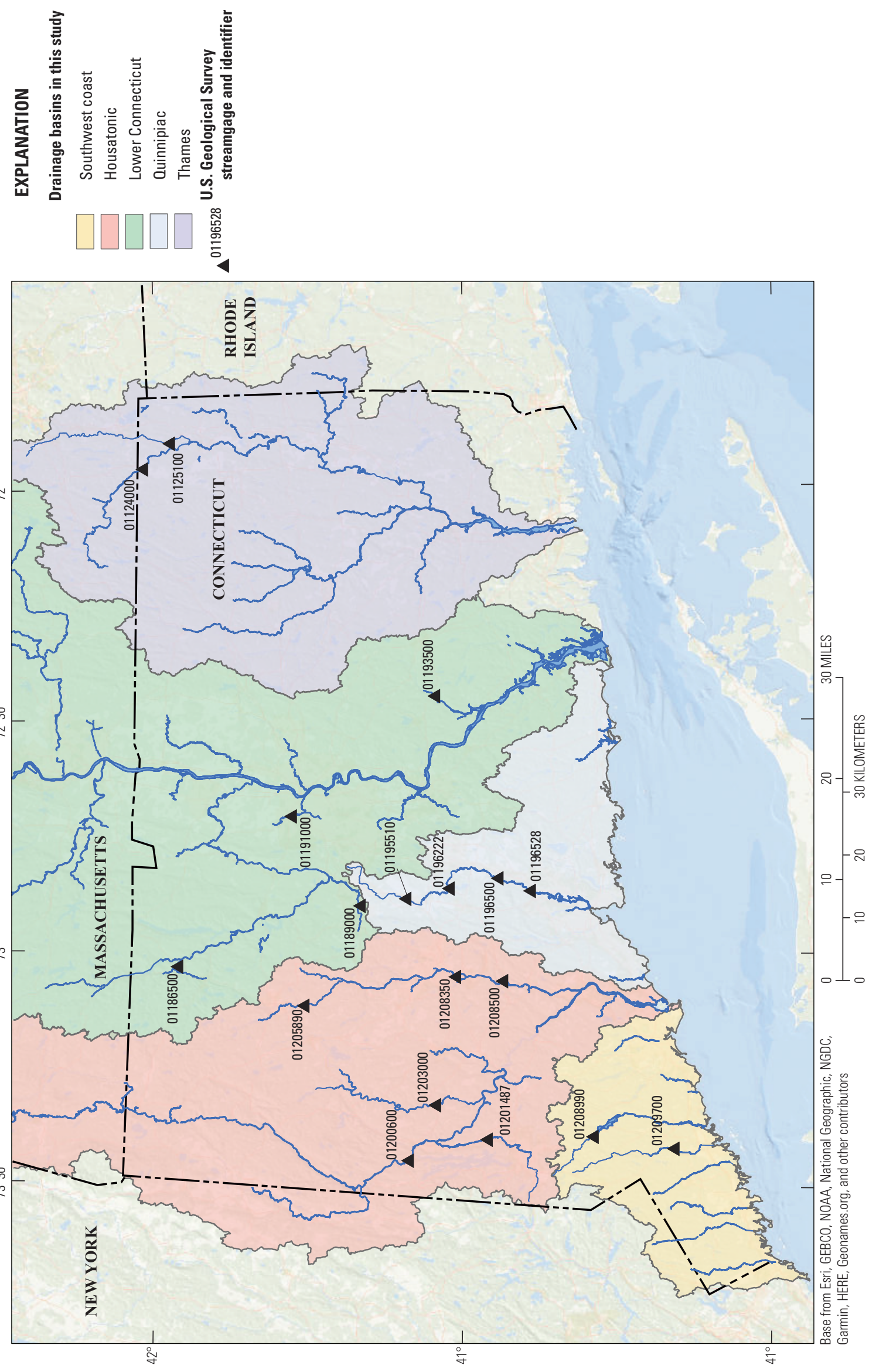

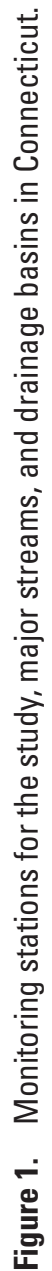




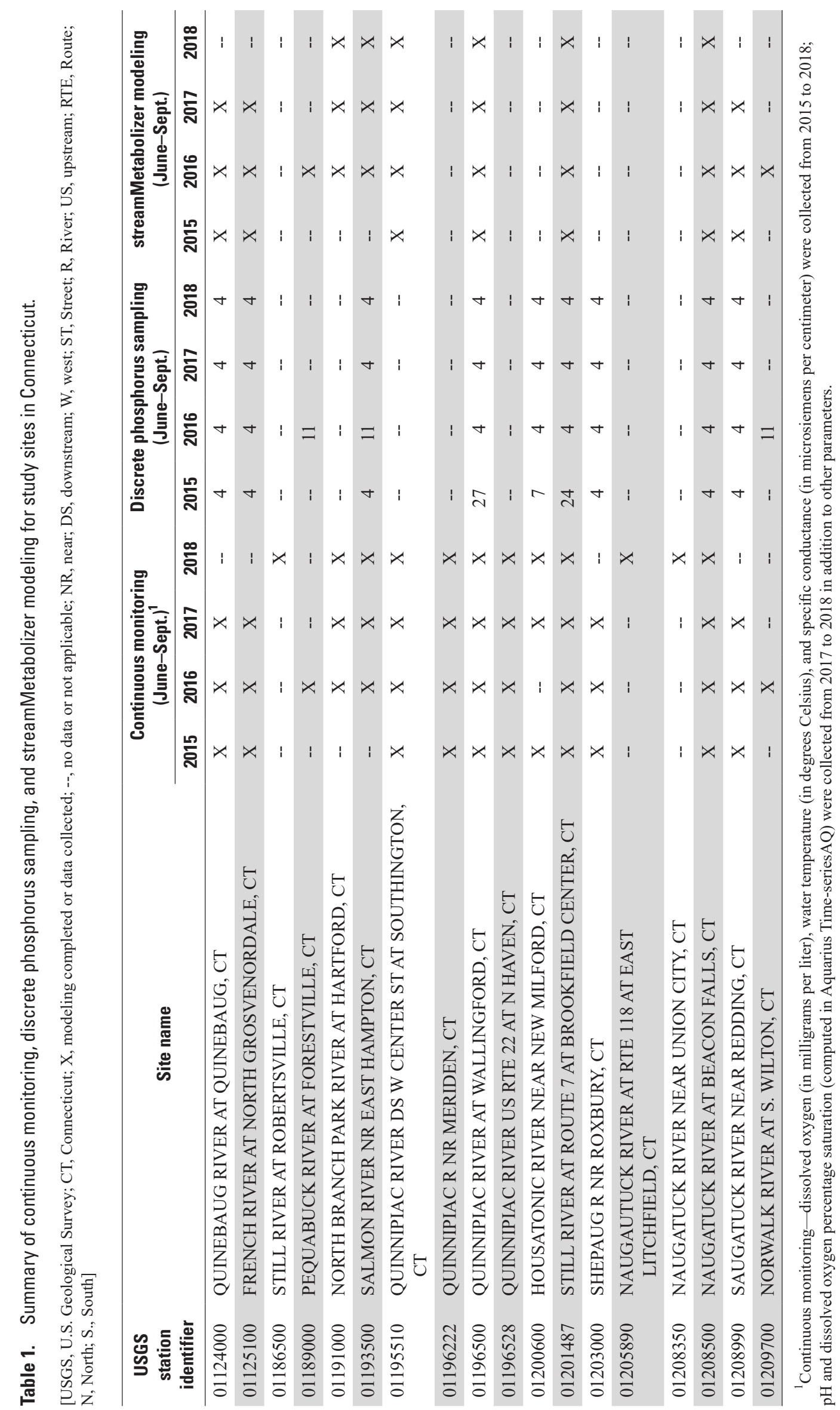




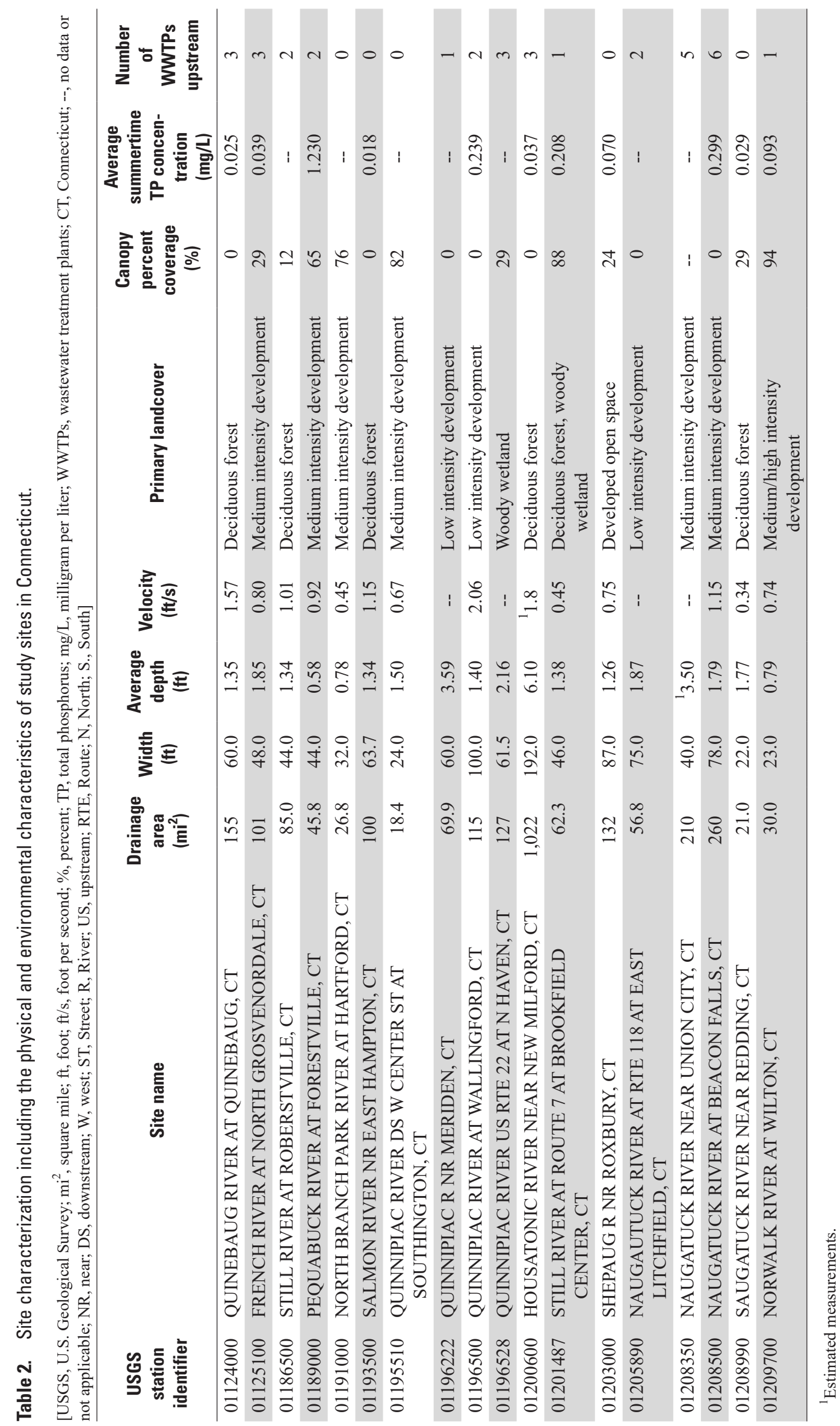




\section{Discrete Sampling Data Collection and Analysis}

Several of the sites monitored for continuous DO in this study were colocated at sites that are part of the USGS and CT DEEP ambient water-quality monitoring network. These sites have discrete water-quality samples collected for nutrients (various forms of phosphorus and nitrogen) and other analytes at varying frequencies throughout the year. All samples were analyzed at the USGS National Water Quality Laboratory in Denver, Colorado, using methods described by Fishman (1993), Patton and Truitt (2000), and Patton and Kryskalla (2011). Discrete water-quality samples were collected using procedures described in the USGS Field Manual (U.S. Geological Survey, 2008). Sites with discrete water-quality data, as well as the sample numbers that are concurrent to the periods of data collection for this study, are shown in table 1. The Quinnipiac River at Wallingford (USGS station 01196500), Housatonic River near New Milford, and Still River at Route 7 at Brookfield Center (USGS station 01201487; hereafter referred to as "Still River at Brookfield") had increased sampling frequencies as part of a specific study to measure phosphorus fluxes in those drainage basins.

\section{Stream Metabolism Computations}

The streamMetabolizer package (version 0.10.9) was used at 11 of the 18 sites that had sufficient data to model daily estimates of average GPP and ER. Data generated during this study are available in Izbicki and Morrison (2021). Naugatuck River at Beacon Falls (USGS station 01208500), Still River at Brookfield, Quinnipiac River at Wallingford, and Quinnipiac River downstream from West Center Street at Southington (USGS station 01195510) were run for all 4 years of the study. The estimates were made from direct observations of DO concentrations, water temperature, and average depth from a single location in the channel, as well as barometric pressure and photosynthetic active radiation (PAR). Whole-stream metabolism was estimated using an open channel, single station approach based on Odum (1956). The model makes implications about metabolic activity at the monitoring locations and the upstream reach (Odum, 1956). A general assessment of the monitoring location and upstream reach of about 150 feet (ft) was made to better understand the instream habitat of the reach. Depth and width measurements were compared to the upstream reach at most sites to assess variation.

Streams have a constant exchange of oxygen concentrations with the atmosphere, which requires empirical estimates of K600 to better estimate the metabolic rates in streams. $\mathrm{K} 600$ is the daily average value of the standardized gas exchange rate coefficient scaled to a Schmidt number of 600 (Appling and others, 2018b; Holtgrieve and others, 2010). The MLE model was used to estimate metabolism and K600 values. This inverse model classifies GPP and ER values that produce the best fit between modeled and observed DO concentrations.

\section{Model Input Variables}

The input variables required to fit the MLE model were solar time, DO concentration, DO saturation, depth, water temperature, and light. Discharge was optional and was only used to verify that there was no tidal effect, which would be apparent if certain periods had indicated discharge was negative. Available time-series data such as DO concentrations, water temperature, gage height, and available PAR data were retrieved from the USGS NWIS database. Not all monitoring stations collected continuous gage height or continuous PAR data. Sites that did have continuous gage height, which is needed to calculate time-varying stream depth, were able to be used in streamMetabolizer for this report. For sites that did not have continuous PAR data available, PAR data were calculated in the streamMetabolizer package using modeled light according to the latitude and longitude of each site. Additional data collected were barometric pressure and calculations of average depth. Stream depth was derived as the average of the cross-sectional depth measurements at the monitor location. The cross-sectional depth measurements were obtained through discharge measurements of 20 section measurements that recorded depth only. Continuous depth estimates were calculated by an equation that related continuous stage data to the actual depths that were measured when the cross-sectional depth data were collected (average depth - associated stage data $=$ depth correction for streamMetabolizer). Continuous barometric pressure data were collected in 2017 and 2018 using Onset HOBO water level loggers, which allowed DO saturation to be calculated. Data were recorded in 15-minute intervals near all stations where change in air pressure was minimal. To calculate DO saturation for 2015 and 2016, the Northeast Regional Climate Center at Cornell University provided hourly barometric pressure data for these years from weather stations at nearby airports: Bradley International Airport, Tweed-New Haven Regional Airport, and Igor I. Sikorsky Memorial Airport. The 15-minute barometric pressure data were interpolated from the hourly data and corrected for altitude using an approximate formula provided by Yellow Springs Instrument: true barometric pressure $=($ corrected barometric pressure $)-(2.5 *$ [local altitude, in feet above sea level/100]) (https://www.ysi.com/ysi-blog/water-blogged-blog/ 2017/01/dissolved-oxygen-meters-q-a-the-ultimate-list).

Some input variables required to model metabolism were derived in the streamMetabolizer package. Clock time was converted to mean solar time to determine the timestep length and assign each observation to daily values of GPP, ER, and K600 (Appling and others, 2017). Missing depth and light data were estimated using linear interpolation when deemed effective. If consecutive hours or days of values were missing and the gap fill function could not provide an effective interpolation, estimates were not made for that date and the entire day was omitted (Appling and others, 2017). DO and water temperature variables were not generally interpolated for the streamMetabolizer. The data were removed during the approval process of the time series and were not gap filled, 
with the exception of Norwalk River at South Wilton (USGS station 01209700). Consecutive days were missing one 15-minute DO value, which was estimated by interpolation.

\section{Model Outputs}

The MLE model was used to estimate the metabolism and K600 value with the default parameters. The MLE models are simple and thus do not have many parameters to set; changing any of the specifications for the model does not have significant effects on the resulting output. After fitting the model, the daily metabolism estimates and DO predictions and observations were plotted and examined. The K600 value was estimated by the model, and the time series of daily estimated K600 values was used to determine a mean fixed K600 value for each simulation. The model was rerun using the mean $\mathrm{K} 600$ value specific to each site and year compared to the modeled K600 data. Any large or unrealistic values of K600 were removed in the new model output, and the fixed K600 value indicated less variability for most of the sites when comparing daily values of GPP and ER. The model estimates can sometimes generate unrealistic estimates of GPP, ER, and $\mathrm{K} 600$ values. This is referred to as equifinality and can occur when the metabolism signal strength is weak and the estimates of GPP, ER, and K600 produce similar curves of oxygen (Appling and others, 2018a). Establishing a mean fixed K600 value from the modeled K600 daily estimates helped to avoid equifinality when estimating stream metabolism for each site.

\section{Model Validation}

Technical validation model diagnostics were completed for the study to validate estimates produced from the MLE model. Errors and warnings were extracted after running the model to help identify days with questionable or unrealistic values or possible equifinality. Unrealistic modeled output values were identified as negative GPP values, positive ER values, and estimates that seem significantly higher than normal (normal based on consistency with neighboring days). Days with storm events were left in the dataset unless they caused unrealistic estimates. The Quinnipiac River upstream from Route 22 at North Haven (USGS station 01196528) was not used in estimating metabolism because tidal variation in stage and streamflow occurred. The MLE model for Still River at Robertsville (USGS station 01186500) produced many unrealistic outputs for 2017, even with the fixed K600 value, and the estimates were not used in the analysis. A qualitative scale was used to estimate model confidence of GPP and ER outputs based on the number of days with negative GPP and positive ER. Low, medium, and high model confidences were assigned based on the following scale: high confidence was 0 to 5 days, medium confidence was 6 to 10 days, and low confidence was 11 days or more. K600 coefficient variations for $0-50,50-100$, and greater than 100 have confidences of high, medium, and low, respectively. For many K600 modeled values that were greater than 100 , confidence is still high although the values fall in the medium or low criteria. This is based on the confidence of the fixed K600 values and the consistency between years for each site. Qualitative assessments of each model are compiled by site and year (table 3 ).

\section{Analysis of Dissolved Oxygen Concentrations}

DO values fluctuated at each site from June through September. The highest concentrations of DO occurred at the Naugatuck River at Beacon Falls where DO concentrations were as high as 13.8 milligrams per liter $(\mathrm{mg} / \mathrm{L})$, which was 178 percent of saturation (table 4). During the study, most stations recorded minimum values greater than the State's water-quality standard of $5 \mathrm{mg} / \mathrm{L}$ (Connecticut Department of Environmental Protection, 2011); however, several stations did have values less than $5 \mathrm{mg} / \mathrm{L}$. North Branch Park River at Hartford recorded the lowest DO concentration $(1.6 \mathrm{mg} / \mathrm{L}$ in July 2016) with many days having values less than $5 \mathrm{mg} / \mathrm{L}$ from 2016 to 2018 . This station also had the most consecutive days with the minimum daily DO values less than $5 \mathrm{mg} / \mathrm{L}$, having 16 days recorded during 2016. Still River at Brookfield, Quinnipiac River upstream from Route 22 at North Haven, Quinnipiac River near Meriden, and Quinnipiac River downstream from West Center Street at Southington recorded DO values less than $5 \mathrm{mg} / \mathrm{L}$ during 2016 and 2018 with the lowest instantaneous value of $3.9 \mathrm{mg} / \mathrm{L}$ recorded at Quinnipiac River near Meriden during 2018. Colder water holds more DO, so monitoring stations that were colder tended to have higher concentrations of DO. The daily ranges of oxygen concentrations and temperature for each of the stations measured are shown in figure 2. Water temperatures ranged from 13.4 to 31.8 degrees Celsius $\left({ }^{\circ} \mathrm{C}\right)$ during the study with the predominately forested sites having the lowest and Naugatuck River at Beacon Falls having the highest. The maximum daily water temperature at most sites was recorded during 2016, which was likely due to low-flow conditions that most streams experienced in Connecticut during 2016. In general, the urban sites tended to have higher water temperatures; however, the Salmon River near East Hampton (USGS station 01193500) had the largest daily range in water temperature during the study with $9.5^{\circ} \mathrm{C}$.

DO concentrations fluctuated at monitored stations daily. These daily fluctuations (diel cycles) are the result of changes in oxygen concentrations from primary productivity and respiration in each of the monitored stations. This can be seen in data from the North Branch Park River at Hartford (fig. 3) that document how changes in $\mathrm{DO}$ and $\mathrm{pH}$ concentrations recorded throughout the day at the sites indicate that both constituents often were lowest in the early morning, before photosynthesis begins to supply oxygen in the stream and assimilate carbon dioxide in the process. After sunset, $\mathrm{DO}$ would begin to decrease as the gross respiration in the stream would begin 


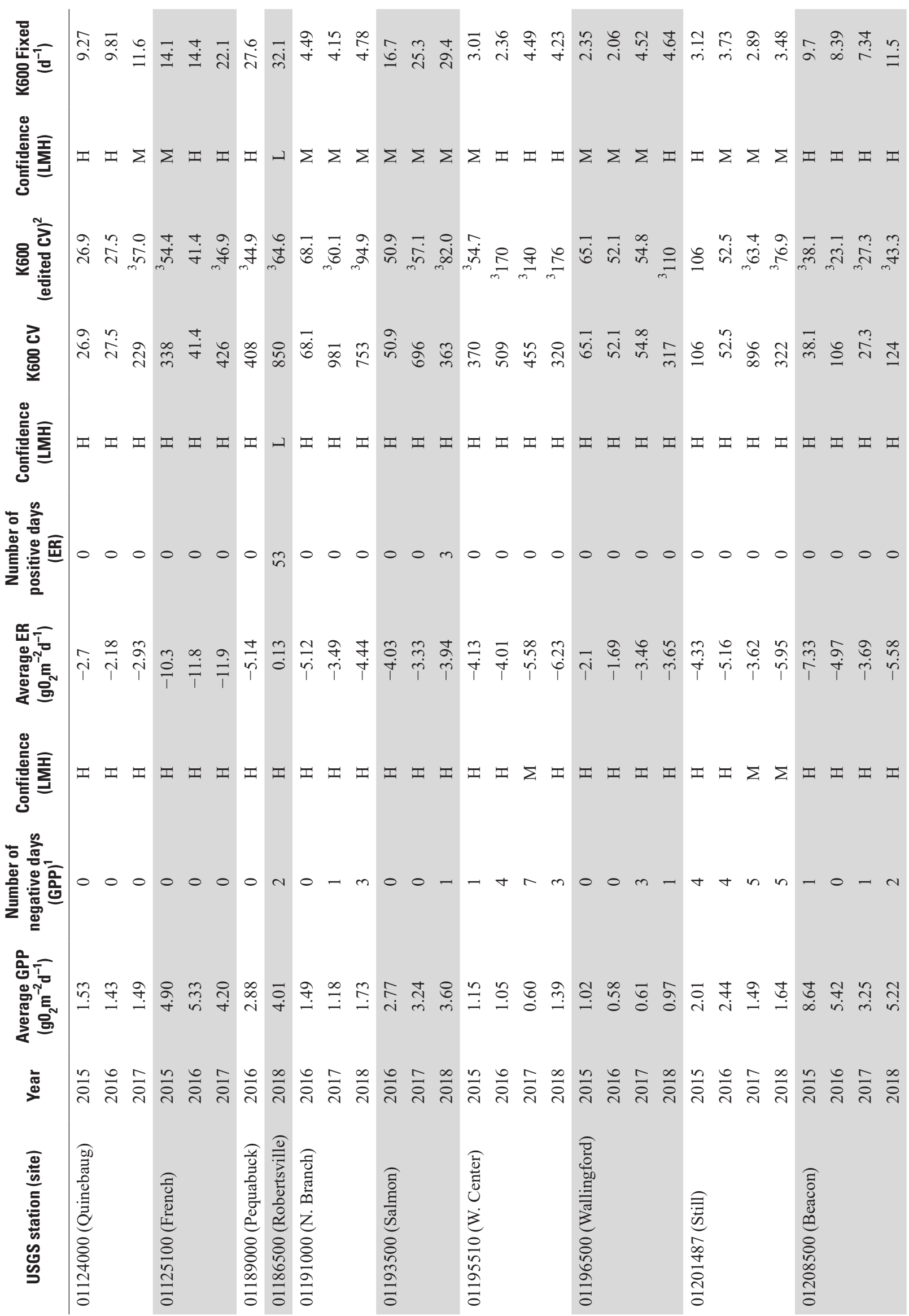




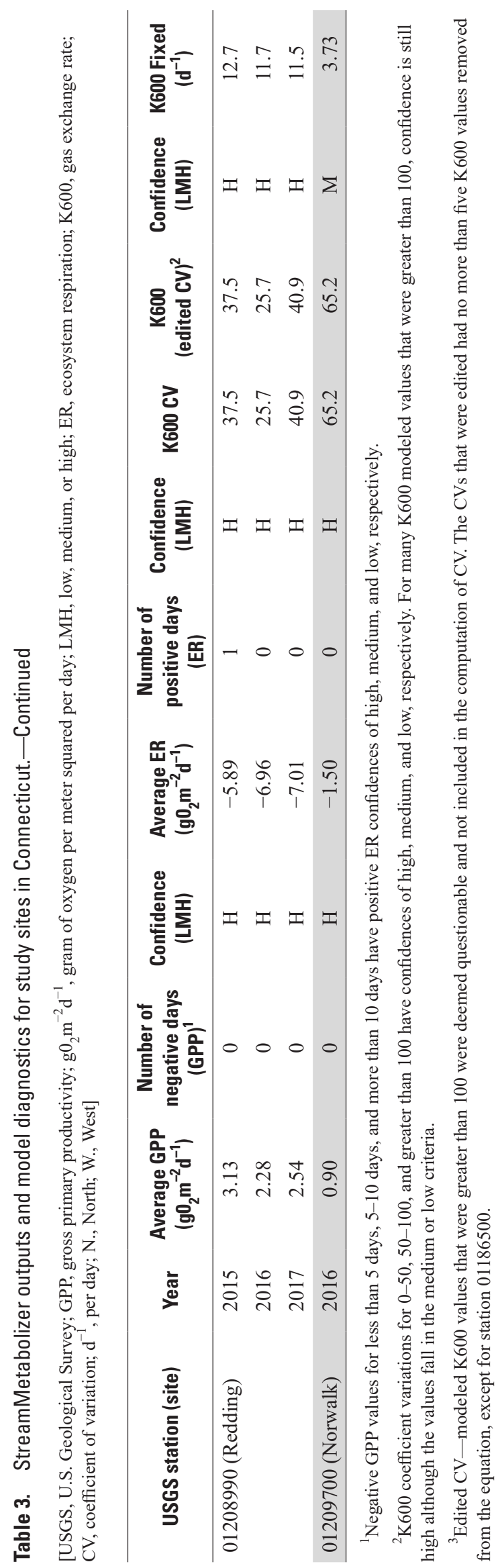




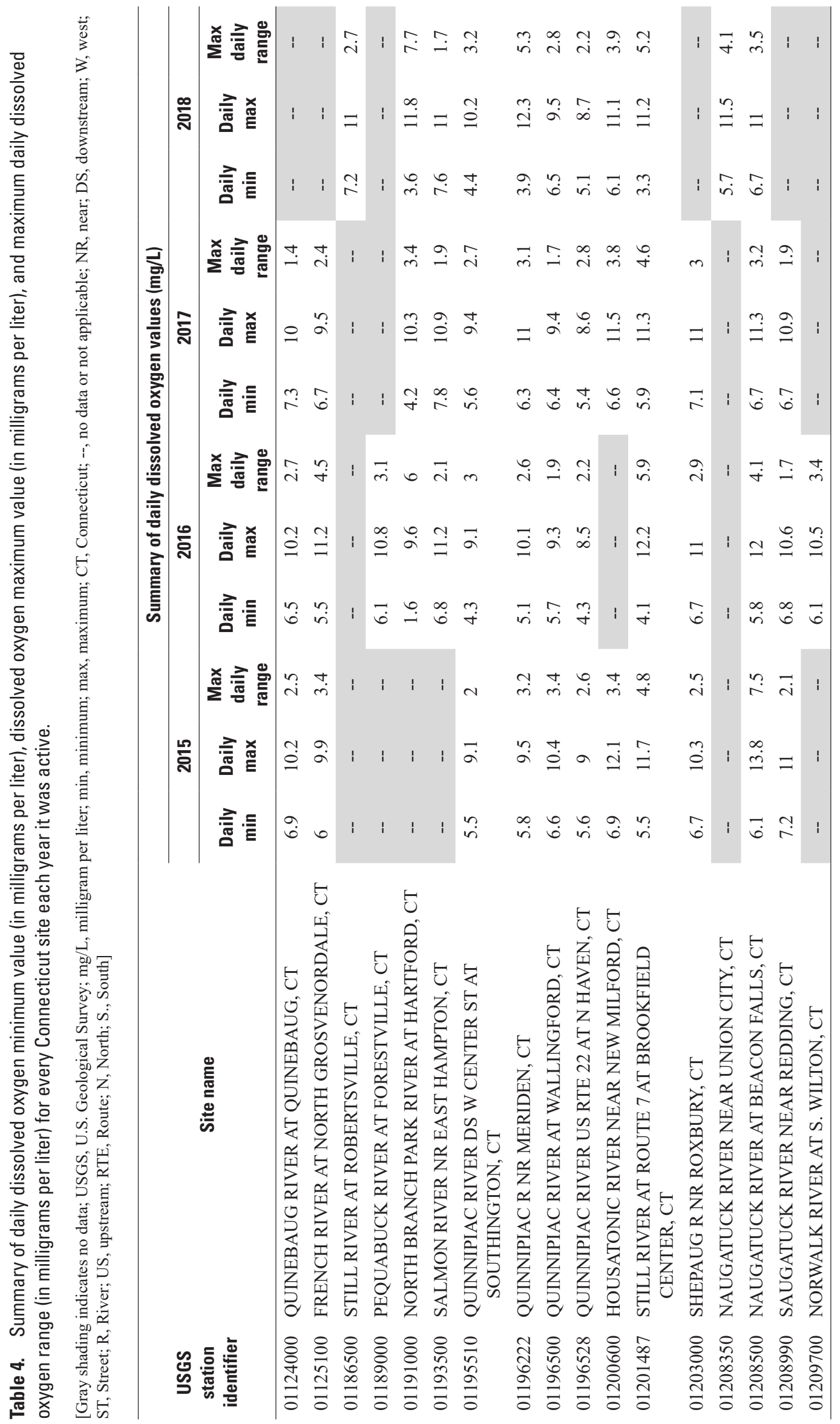



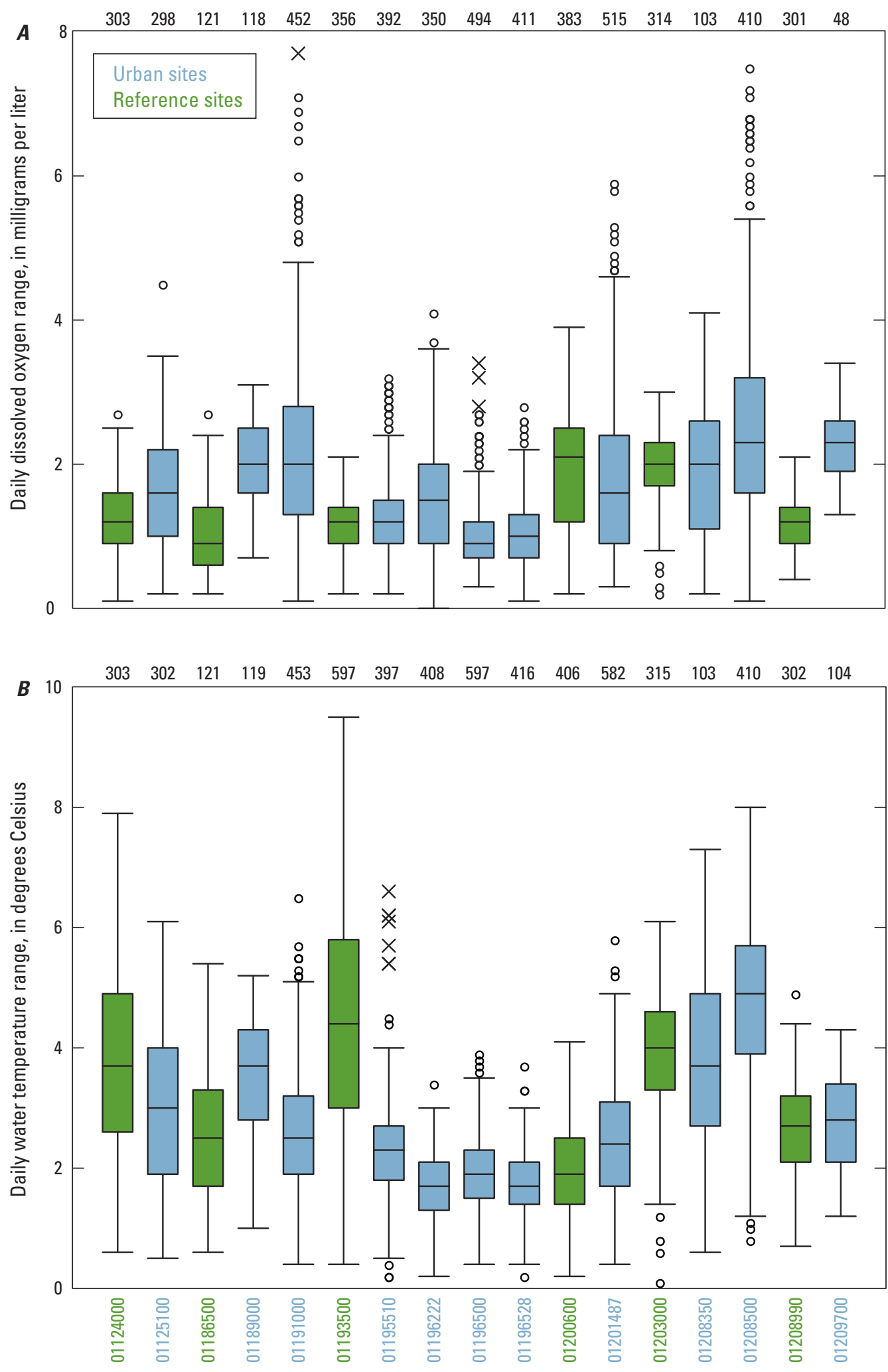

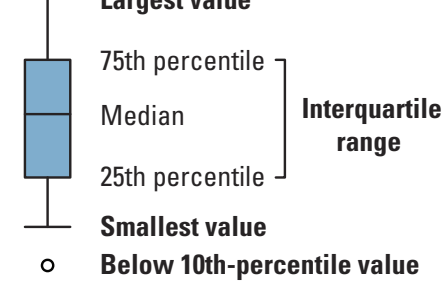

\section{EXPLANATION}

303 Number of values

$\times \quad$ Far-out value

○ Above 90th-percentile value Largest value

75th percentile

Median quartile

- Below 10th-percentile value

Monitoring sites 2015-18 (June-September)

Figure 2. Daily ranges in study sites in Connecticut across the 4 years (June-September). $A$, daily dissolved oxygen range (in milligrams per liter); $B$, daily water temperature range (in degrees Celsius). 


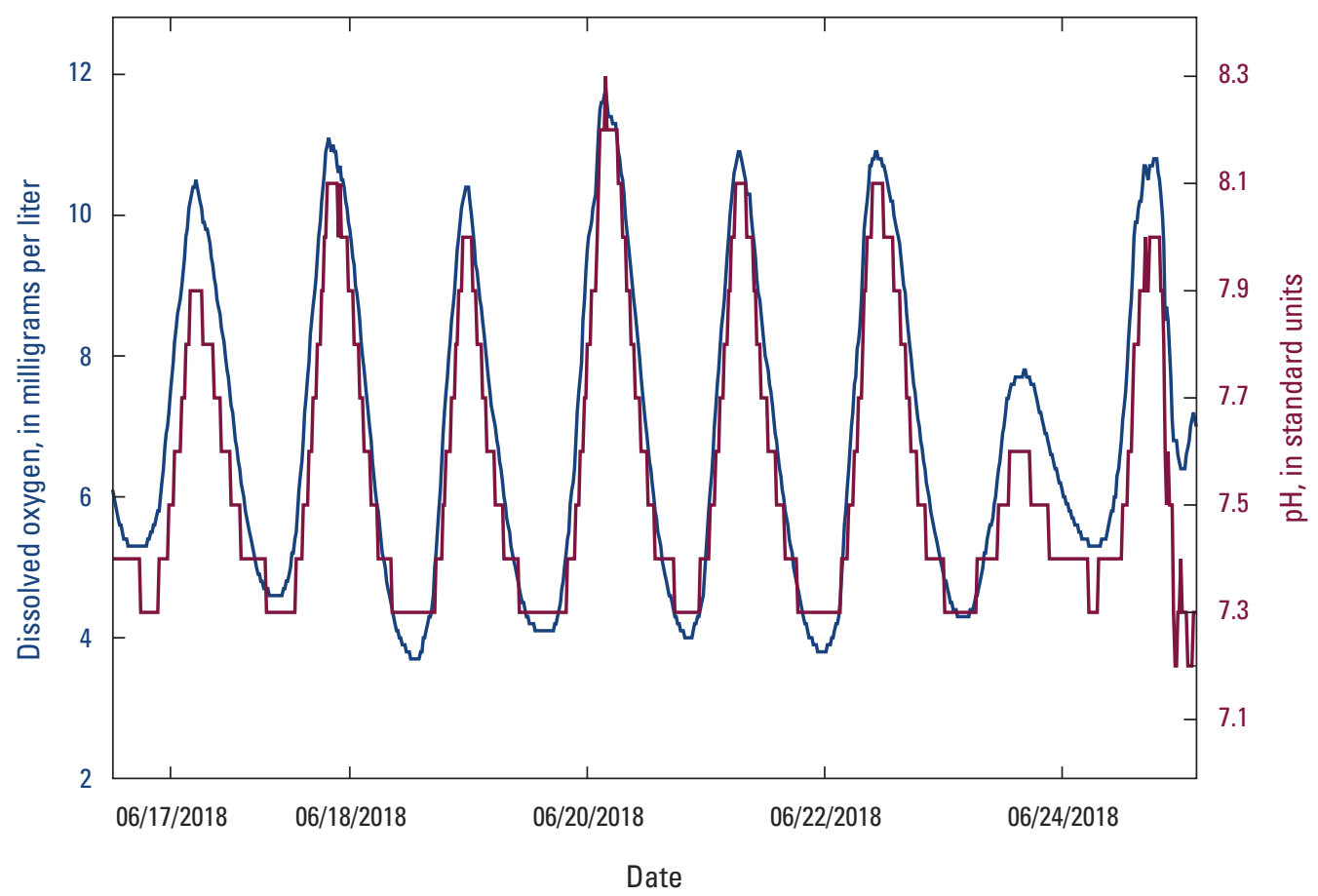

Figure 3. Daily fluctuations of dissolved oxygen (in milligrams per liter) and pH (in standard units) in response to stream metabolism for North Branch Park River at Hartford, Connecticut (U.S. Geological Survey station 01191000).

to consume oxygen and release carbon dioxide to the stream, lowering the $\mathrm{DO}$ and $\mathrm{pH}$. The large diel cycles at some sites are a result of a productive ecosystem.

This study focused on maximum daily DO ranges, which may be a beneficial metric for stream assessment. Large diurnal DO fluctuations can be unhealthy for stream biota. Maximum daily DO ranges from the study ranged from 1.4 to $7.7 \mathrm{mg} / \mathrm{L}$, with reference sites typically having ranges of daily DO that were often less than $2 \mathrm{mg} / \mathrm{L}$ and most sites downstream from wastewater treatment plants having ranges greater than $2 \mathrm{mg} / \mathrm{L}$ (table 4). The Naugatuck River at Beacon Falls, Still River at Brookfield, and North Branch Park River at Hartford had the largest maximum daily DO ranges. Still River at Brookfield recorded a maximum daily DO range of $5.9 \mathrm{mg} / \mathrm{L}$ in 2016. Naugatuck River at Beacon Falls recorded a maximum daily DO range of $7.5 \mathrm{mg} / \mathrm{L}$ in 2015, and North Branch Park River recorded a maximum daily DO range of $7.7 \mathrm{mg} / \mathrm{L}$ in 2018. The four sites along the Quinnipiac River had lower daily DO ranges, generally less than $4 \mathrm{mg} / \mathrm{L}$. Note that Naugatuck River at Route 118 at East Litchfield (USGS station 01205890) was removed from the analysis of daily DO ranges because the monitor was repeatedly buried by sediment for most of 2018 and data recorded from only June to July did not seem representative of the stream conditions for the study.

In general, reference streams (considered unimpaired) indicated lower average summertime concentrations of TP, with concentrations typically less than $0.05 \mathrm{mg} / \mathrm{L}$. Streams identified as impaired by CT DEEP, such as Naugatuck River at Beacon Falls, Still River at Brookfield, and Quinnipiac
River at Wallingford (CT DEEP, 2019), had higher TP concentrations throughout the study. Sites downstream from wastewater treatment plants had TP concentrations greater than and less than $0.1 \mathrm{mg} / \mathrm{L}$ (fig. 4). These results indicate additional factors other than the source of nutrients are affecting instream nutrient concentrations in this study. Instream biogeochemical processes and transport can affect concentrations of phosphorus and should be considered when interpreting effects from phosphorus loading. Most urban sites classified as "low/ medium/high intensity development" (table 2) have TP concentrations at varying flows opposite of what are measured for reference sites. Phosphorus concentrations at Naugatuck River at Beacon Falls come primarily from a point source such as treated wastewater, and low flows generally resulted in higher TP concentrations, which usually occur around the late summer and early fall. During a high-flow event, the phosphorus from treated wastewater is diluted, which lowers concentrations. Reference sites indicate the opposite effects; for example, Salmon River near East Hampton is categorized as "deciduous forest," with higher TP concentrations driven by nonpoint source runoff occurring during high-flow events (fig. 5).

A pattern between average summertime TP concentrations and maximum daily DO ranges generally occurred at each site during the 4 years data were collected (fig. 6). Interannual variability in TP and DO concentrations among sites is documented in all years of the study, and the concentrations tend to cluster by site. The highest DO ranges were at Still River at Brookfield for all 4 years and Naugatuck River 


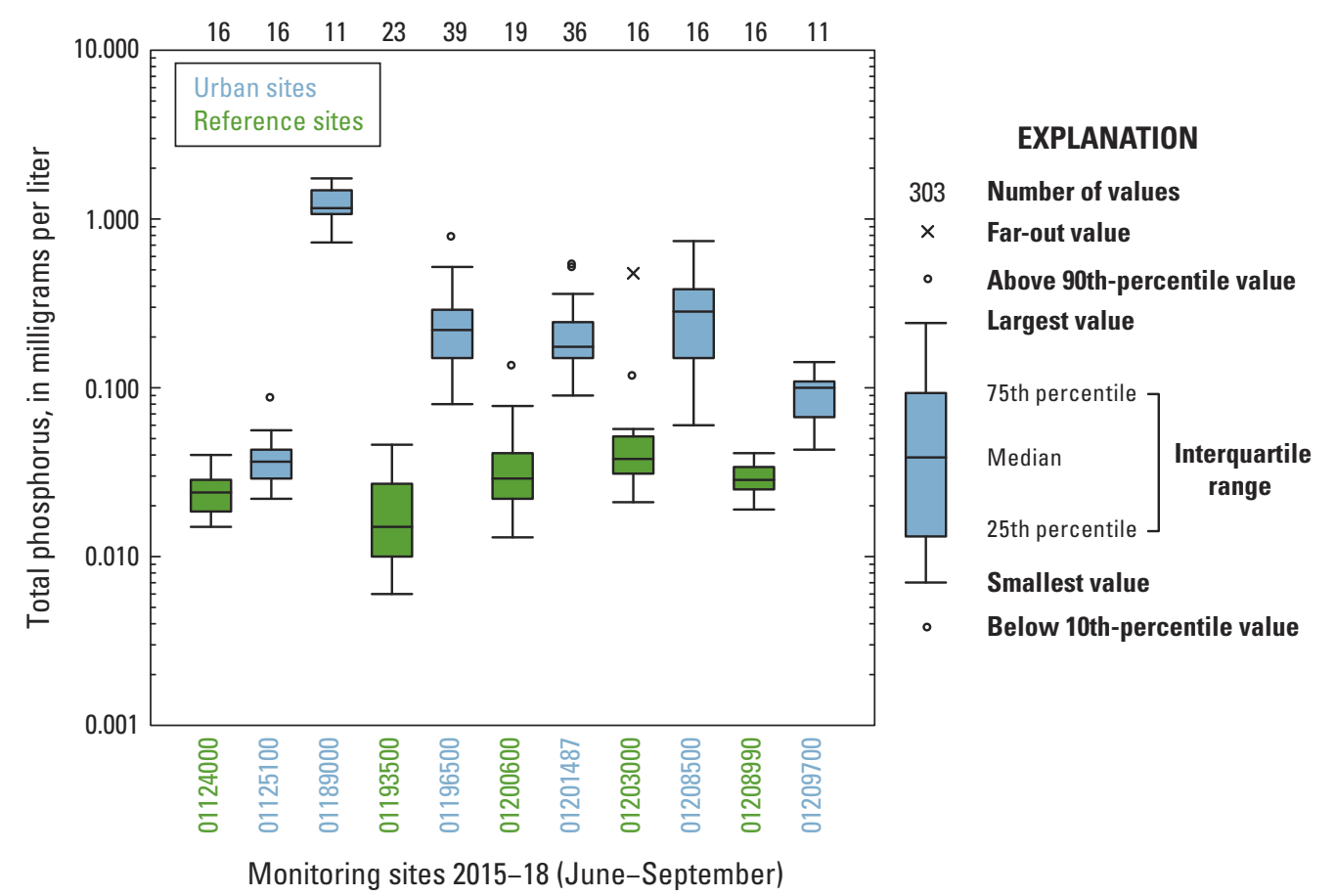

Figure 4. Total phosphorus concentrations at selected sites in Connecticut with discrete sampling data during the study for June-September.
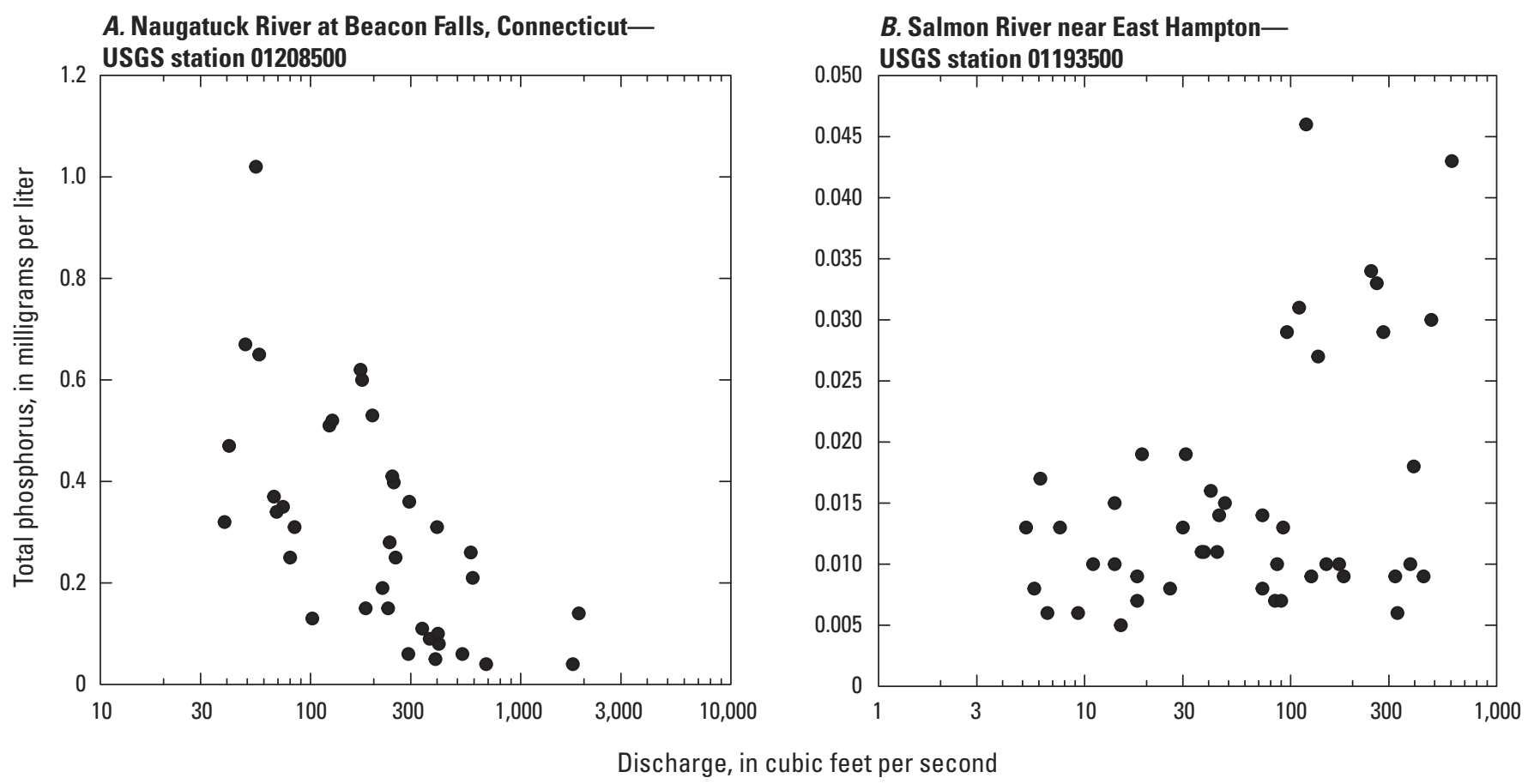

Figure 5. Total phosphorus concentrations (in milligrams per liter) against discharge (in cubic feet per second) for selected sites in Connecticut. $A$, point sources dominating the urban site; $B$, nonpoint sources dominating the reference site. [USGS, U.S. Geological Survey] 


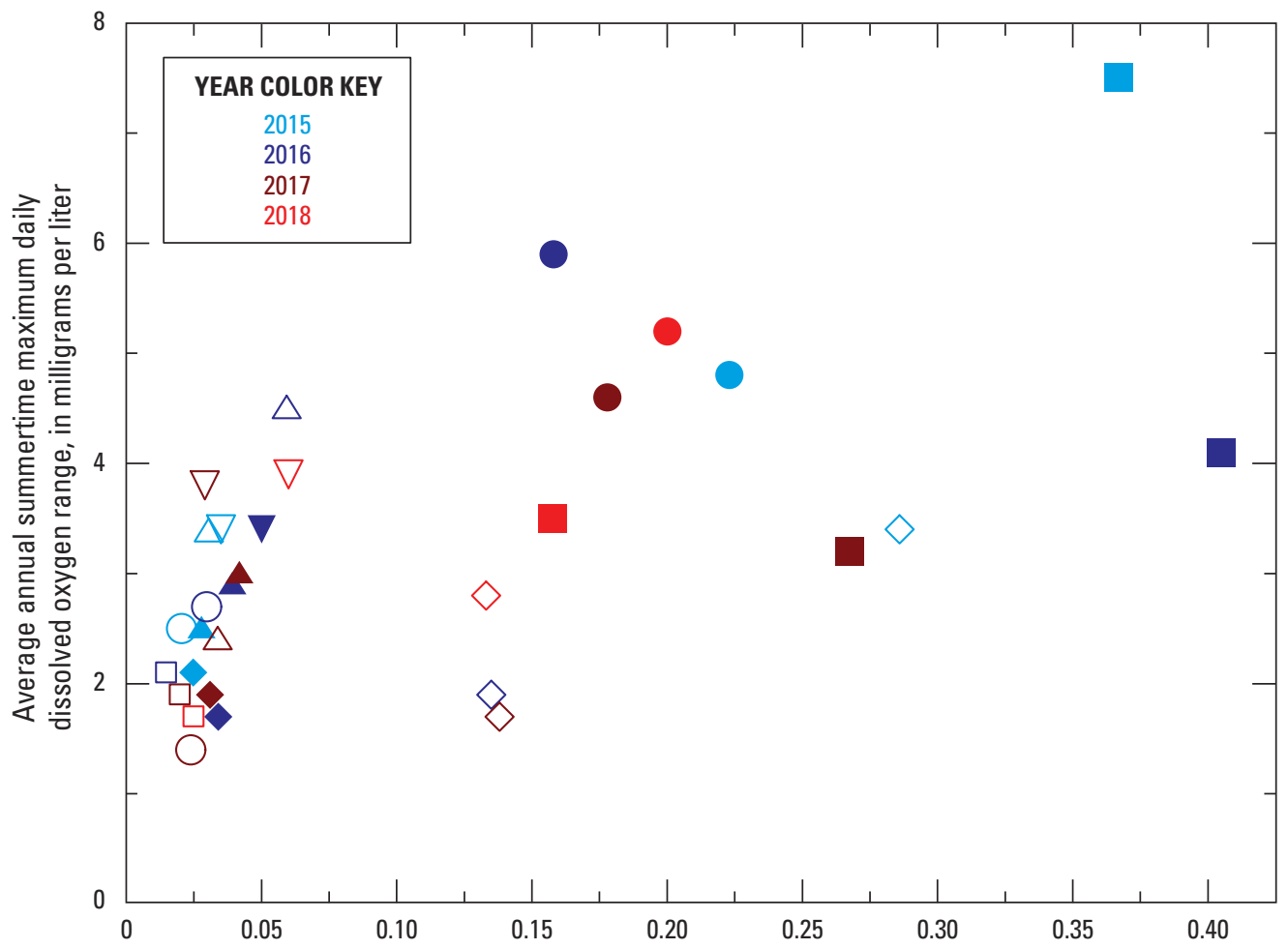

Average annual summertime total phosphorus concentration, in milligrams per liter

\section{EXPLANATION}

\section{Site identifiers}

$\bigcirc$ Quinebaug River at Quinebaug-U.S. Geological Survey (USGS) station 01124000

$\triangle$ French River at North Grosvenordale - USGS station 01125100

$\square$ Salmon River near East Hampton-USGS station 01193500

$\diamond$ Quinnipiac River at Wallingford —USGS station 01196500

$\nabla$ Housatonic River near New Milford—USGS station 01200600

- Still River at Route 7 at Brookfield Center-USGS station 01201487

- Shepaug River near Roxbury — USGS station 01203000

- Naugatuck River at Beacon Falls_-USGS station 01208500

- Saugatuck River near Redding -USGS station 01208990

$\nabla$ Norwalk River at South Wilton-USGS station 01209700

Figure 6. Average annual summertime maximum daily dissolved oxygen range (in milligrams per liter) and average annual summertime total phosphorus concentrations (in milligrams per liter) for study sites in Connecticut for June-September. 
at Beacon Falls for 2015. Most reference sites had an average TP concentration that did not exceed $0.05 \mathrm{mg} / \mathrm{L}$ and had lower maximum daily DO range values of less than $2 \mathrm{mg} / \mathrm{L}$. Still River at Brookfield, Quinnipiac River at Wallingford, and Naugatuck River at Beacon Falls had TP concentrations greater than $0.10 \mathrm{mg} / \mathrm{L}$. Although these sites had the highest TP concentrations during the study, Quinnipiac River at Wallingford did not exceed daily DO ranges of $4 \mathrm{mg} / \mathrm{L}$. The sites downstream from municipal wastewater treatment plants with lower daily DO ranges could be affected by variables such as water temperature and velocity in the reach upstream from the monitor. Note that Pequabuck River at Forestville (USGS station 01189000) was not included in the graph because of significantly higher TP concentrations. Pequabuck River at Forestville had the highest average summertime concentrations of TP, greater than $1 \mathrm{mg} / \mathrm{L}$ in 2016 with a maximum daily DO range of $3.1 \mathrm{mg} / \mathrm{L}$, and caused the scale to be skewed to the right. This site has a high percentage of urbanized land use in the watershed drainage basin and tends to be shallow with rapidly changing discharge during runoff events.

Streamflow is another important variable that affects water-quality response in streams; this additional information helps in understanding how DO varies as environmental conditions change. Streamflow during the data-collection periods varied within a year and from year to year. During the study, 10 sites were at stream gaging stations and 2 sites were close enough to provide reliable streamflow data for these sites. Average streamflows were computed during the summer months (June-September) for each year the site was active for the project and compared to the 30-year summertime average; however, at 4 of the 12 sites, 30 years of data were not available, so average summertime streamflows were compared to the record of data that was available. The 2016 average summertime streamflow was less than 45 percent of the 30 -year average for all sites and had the lowest percentage of longterm summertime average streamflow during all 4 years of the study. The 2018 average summertime streamflow was greater than 80 percent of the 30 -year average for all sites and the highest percentage of long-term summertime average streamflow during all 4 years of the study.

When observing the pattern in daily DO ranges and TP concentrations over the 4-year study, the Naugatuck River at Beacon Falls was the most notable, where the daily DO ranged from $7 \mathrm{mg} / \mathrm{L}$ in 2015 to less than $4 \mathrm{mg} / \mathrm{L}$ during the remaining years of the study (fig. 6). The Waterbury wastewater treatment plant discharges into the Naugatuck River upstream from Beacon Falls and underwent interim phosphorus reductions in 2015, according to the Waterbury NPDES monitoring report from the EPA Discharge Monitoring Report website for Waterbury (https://www.epa.gov/compliance/dischargemonitoring-report-quality-assurance-study-program). The data indicated that DO and TP concentrations in the Naugatuck River at Beacon Falls decreased throughout the study. Significant changes occurred in the daily DO concentrations from 2015 to 2018. In 2015, daily DO ranges were as high as $7 \mathrm{mg} / \mathrm{L}$ and gradually decreased throughout the remainder of the study. From 2016 to 2018, the maximum daily DO ranges did not exceed $4 \mathrm{mg} / \mathrm{L}$. The average TP concentrations at Naugatuck River at Beacon Falls decreased as well from $0.367 \mathrm{mg} / \mathrm{L}$ in 2015 to $0.158 \mathrm{mg} / \mathrm{L}$ in 2018 . All NPDES permittees discharging to rivers that are not currently meeting water-quality standards (CT DEEP, 303[d]) have interim limits for phosphorus and are working to make upgrades to meet the final limits. TP concentrations in the stream are expected to decrease when final limits are completed (CT DEEP, 2019).

\section{Analysis of Stream Metabolism Outputs}

Estimates of GPP and ER were calculated daily for select sites during the summer periods for the 4 years of the study (table 1). Daily GPP and ER were plotted against each other for the 11 sites where metabolism was modeled (fig. 7). The 1:1 line indicates when GPP $=\mathrm{ER}(\mathrm{NPP}=0)$ and will vary by site. Points above the line indicate heterotrophy, and points below the line indicate autotrophy the day metabolism was estimated. Most sites were estimated to have negative NPP, which indicates the streams were heterotrophic. Streams dominated by respiration require allochthonous inputs of organic matter, which can occur at streams that are tightly connected to landscape and receive large inputs of organic matter, which drives ER (Fisher and Likens, 1973). Streams tend to indicate more variability in metabolism than other aquatic habitats (Hall, 2016). Significant variation in GPP and ER indicated that metabolism varied at some sites during the study, especially the Quinnipiac River downstream from West Center Street at Southington and the Quinnipiac River at Wallingford. Low GPP and highly variable ER were estimated at these two sites, which may be caused by factors such as canopy cover, stream velocity, water temperature, or connection to surrounding landscape (Hall, 2016). The Quinnipiac River downstream from West Center Street at Southington is one of the smallest streams in the study, with closed canopy at the monitor location and upstream reach. The Quinnipiac River at Wallingford had open canopy at the monitoring location, but open canopy was not observed along the upstream reach of the river. In addition, there is a small low-head dam upstream, about onehalf mile from the monitoring location. The Naugatuck River at Beacon Falls had variations between positive and negative NPP, indicating the river was alternating between autotrophic and heterotrophic states throughout all 4 years of the study.

Summertime averages of the daily estimated GPP and ER were also calculated for each year of the study. The maximum daily estimated GPP of 18.89 grams of oxygen per meter squared per day $\left(\mathrm{g}_{2} \mathrm{~m}^{-2} \mathrm{~d}^{-1}\right)$ occurred at Naugatuck River at Beacon Falls during 2015. GPP estimated at Naugatuck River at Beacon Falls had the highest summertime average of $8.64 \mathrm{g0}_{2} \mathrm{~m}^{-2} \mathrm{~d}^{-1}$ during the summer in 2015. French River at North Grosvenordale (USGS station 01125100) and Salmon River near East Hampton had high estimated daily average 

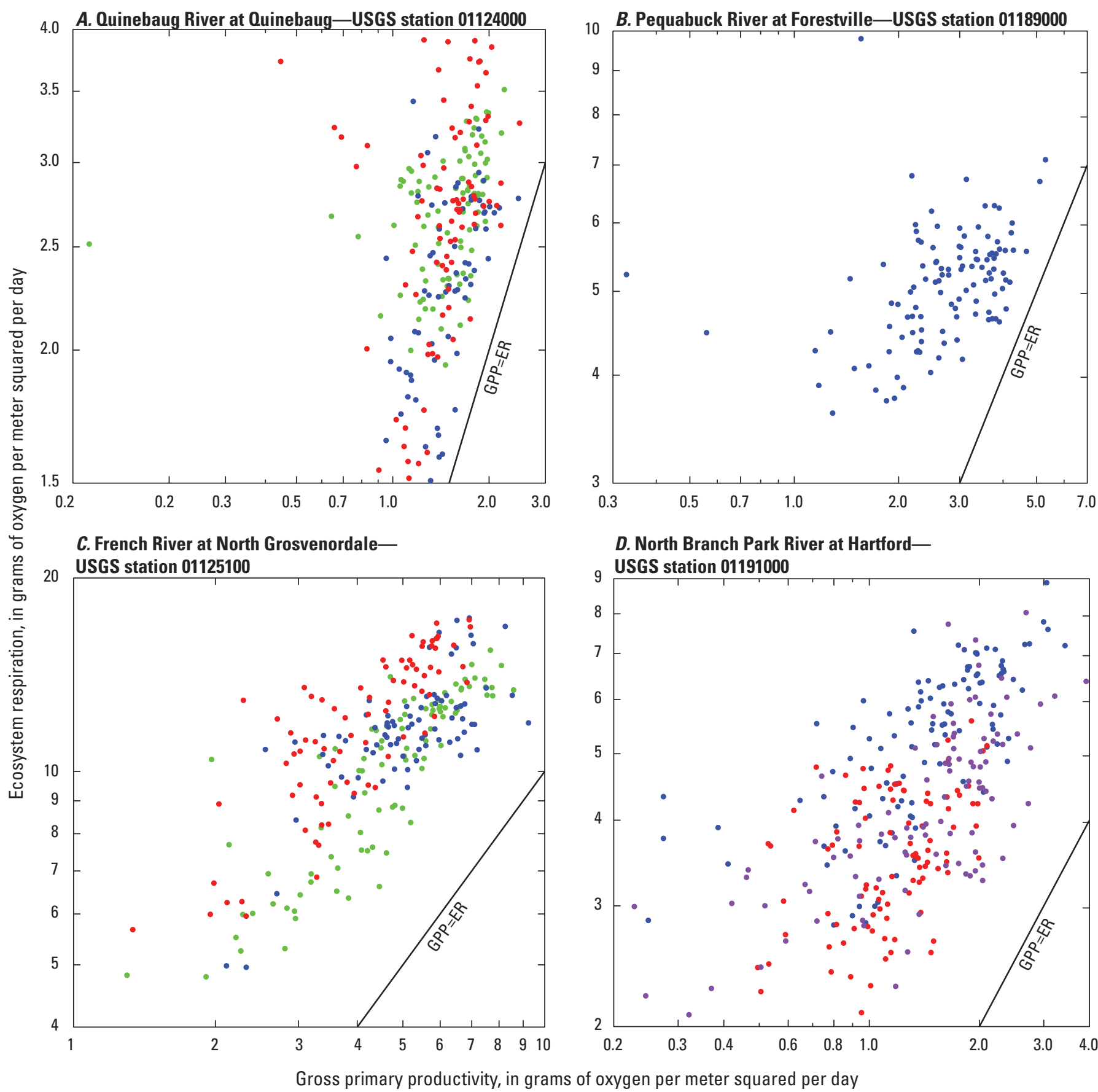

D. North Branch Park River at Hartford9 USGS station 01191000

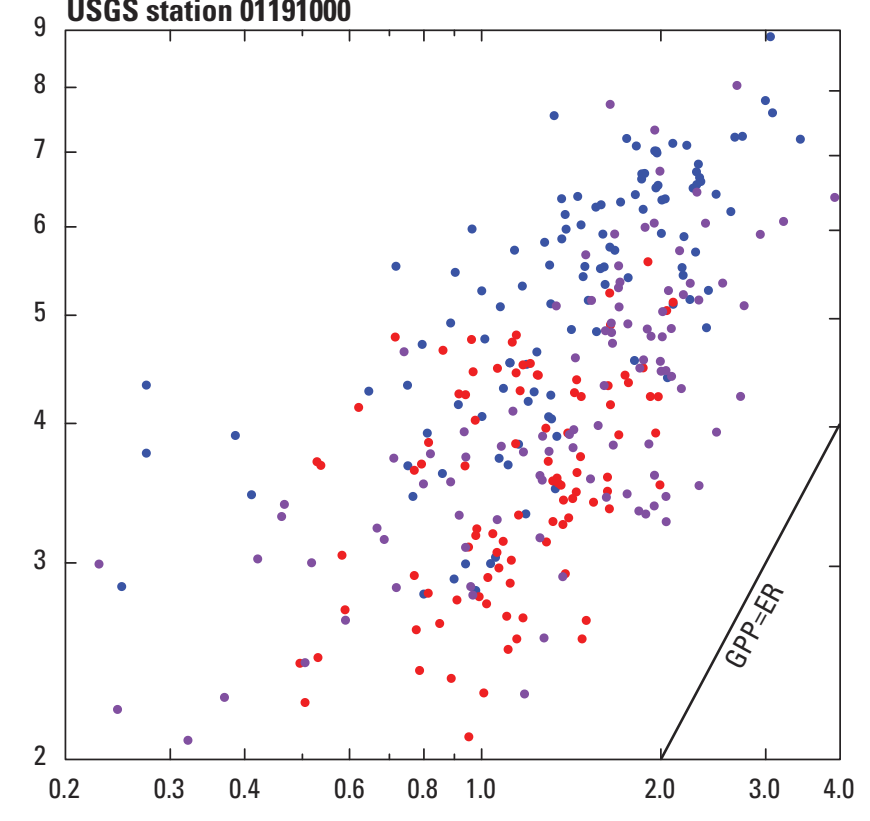

Gross primary productivity, in grams of oxygen per meter squared per day

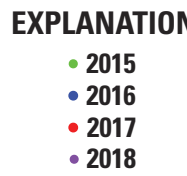

Figure 7. Daily estimates of gross primary productivity (GPP) and ecosystem respiration (ER) for each study site in Connecticut and year it was active. [The $x$ - and $y$-axes are logarithmically scaled. Line is GPP $=E R$, and points above the line indicate heterotrophy on the day metabolism was measured. USGS, U.S. Geological Survey] $A, 2015-17$ summary for station 01124000; $B, 2016$ summary for station 01189000; C, 2015-17 summary for station 01125100; $D$, 2016-18 summary for station 01191000; $E$, 2016-18 summary for station 01193500; F, 2015-18 summary for station 01195510; G, 2015-18 summary for station 01196500; H, 2015-18 summary for station 01201487; I, 2015-17 summary for station 01208990; J, 2016 summary for station 01209700; K, 2015-18 summary for station 01208500 . 

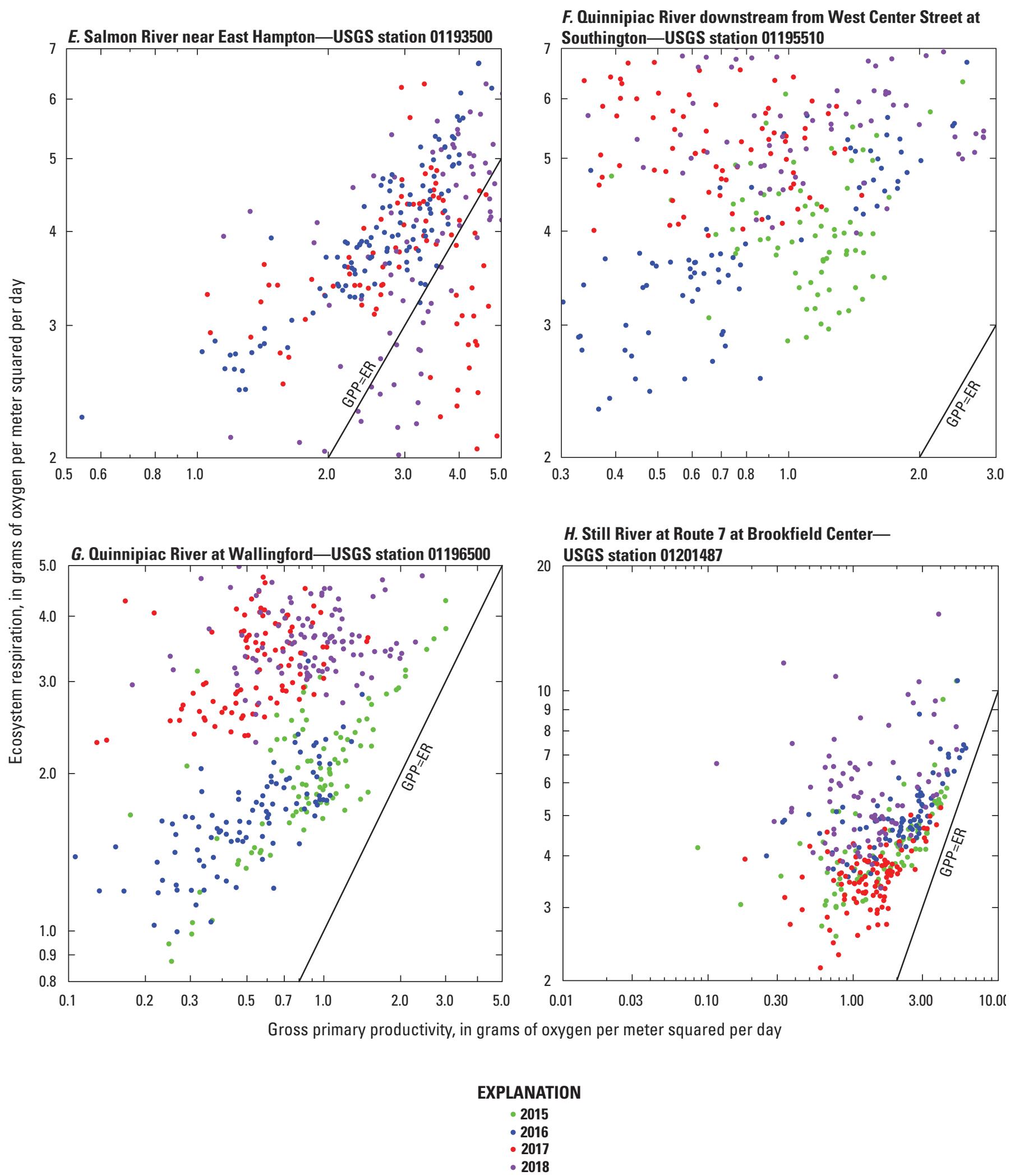

Figure 7.-Continued 

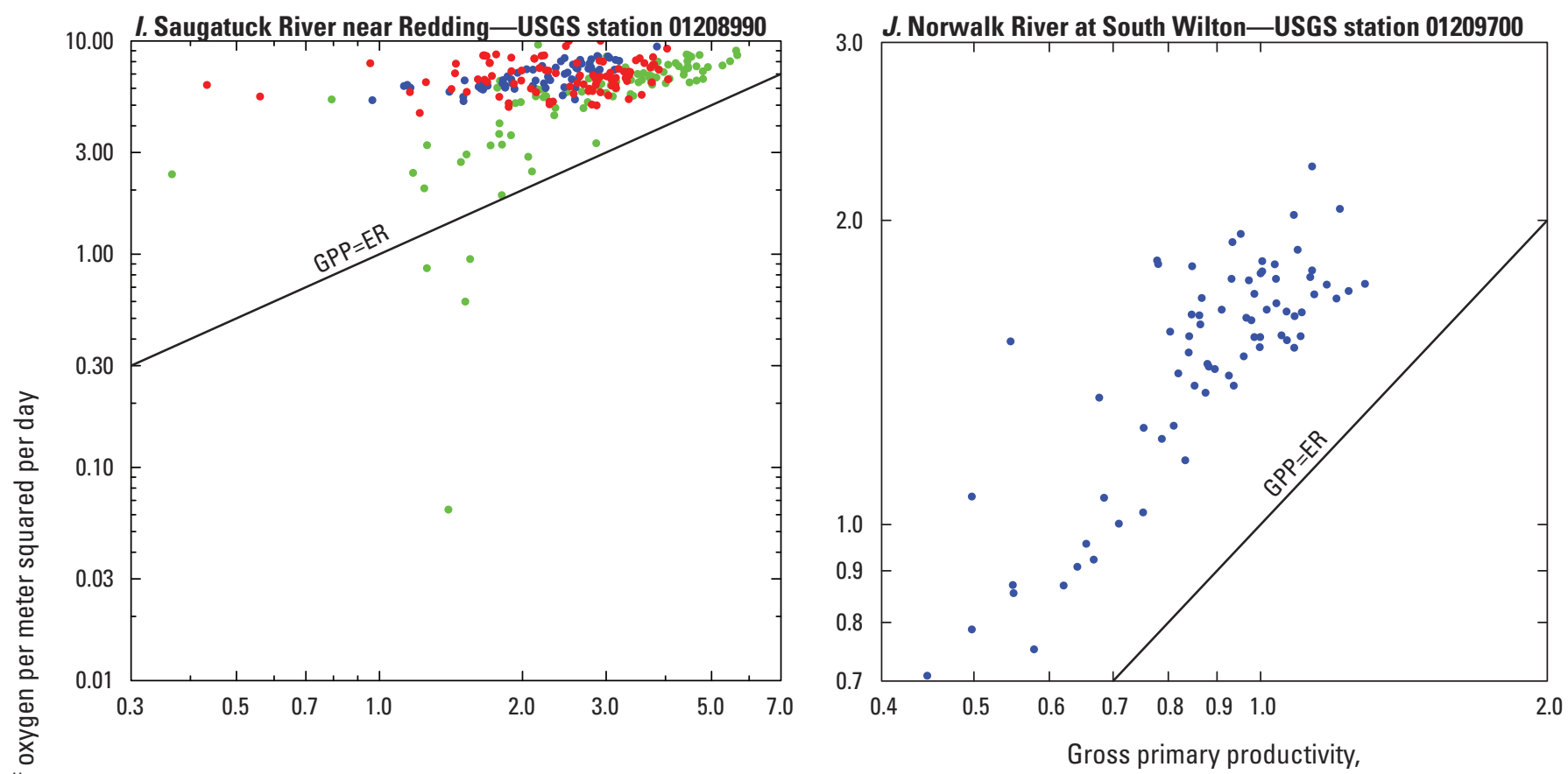

K. Naugatuck River at Beacon FallsUSGS station 01208500

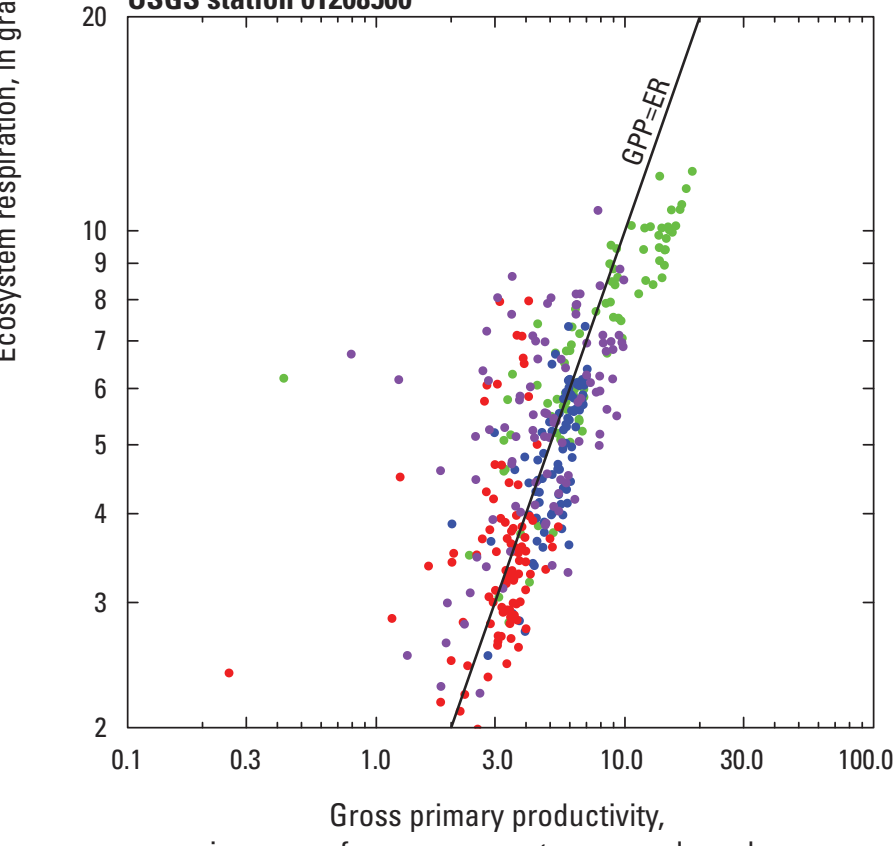

EXPLANATION

- 2015

- 2016

- 2017

- 2018

in grams of oxygen per meter squared per day

Figure 7.-Continued 
GPP values as well. French River at North Grosvenordale estimated the highest summertime average ER at $11.9 \mathrm{~g} 0_{2} \mathrm{~m}^{-2} \mathrm{~d}^{-1}$ in 2017. At Naugatuck River at Beacon Falls, a noticeable decrease occurred in the daily ranges of DO and average TP concentrations since 2015, presumably because of upgrades to the wastewater treatment plant upstream that was previously mentioned. The highest estimated daily rates of GPP and ER occurred at this site in 2015, where GPP and ER were approximately equal and NPP near 0 . This pattern could indicate that reductions in TP resulted in reduced daily ranges of DO, daily estimated GPP, and ER.

The mean GPP was variable across all the urban and reference sites. A lower mean GPP value for the reference sites may be expected because of low nutrient concentrations and lower daily DO ranges limiting productivity in the stream but was not observed after running the MLE model. Naugatuck River at Beacon Falls had the highest mean GPP. Salmon River near East Hampton had rates of GPP higher than expected for a reference site. Both sites measured 0-percent canopy cover at the monitor location, and there was little variation in canopy cover in the upstream reach at both sites of the channel. These two sites also had the largest median daily range in water temperature among all the sites, which may contribute to the high degree in variability in GPP (fig. $2 B$ ).

The pattern between GPP and TP (fig. 8) is similar to the pattern between daily maximum DO range and TP concentration seen in figure 5 for most sites, with GPP values and TP concentrations clustering by site. Still River at Brookfield did

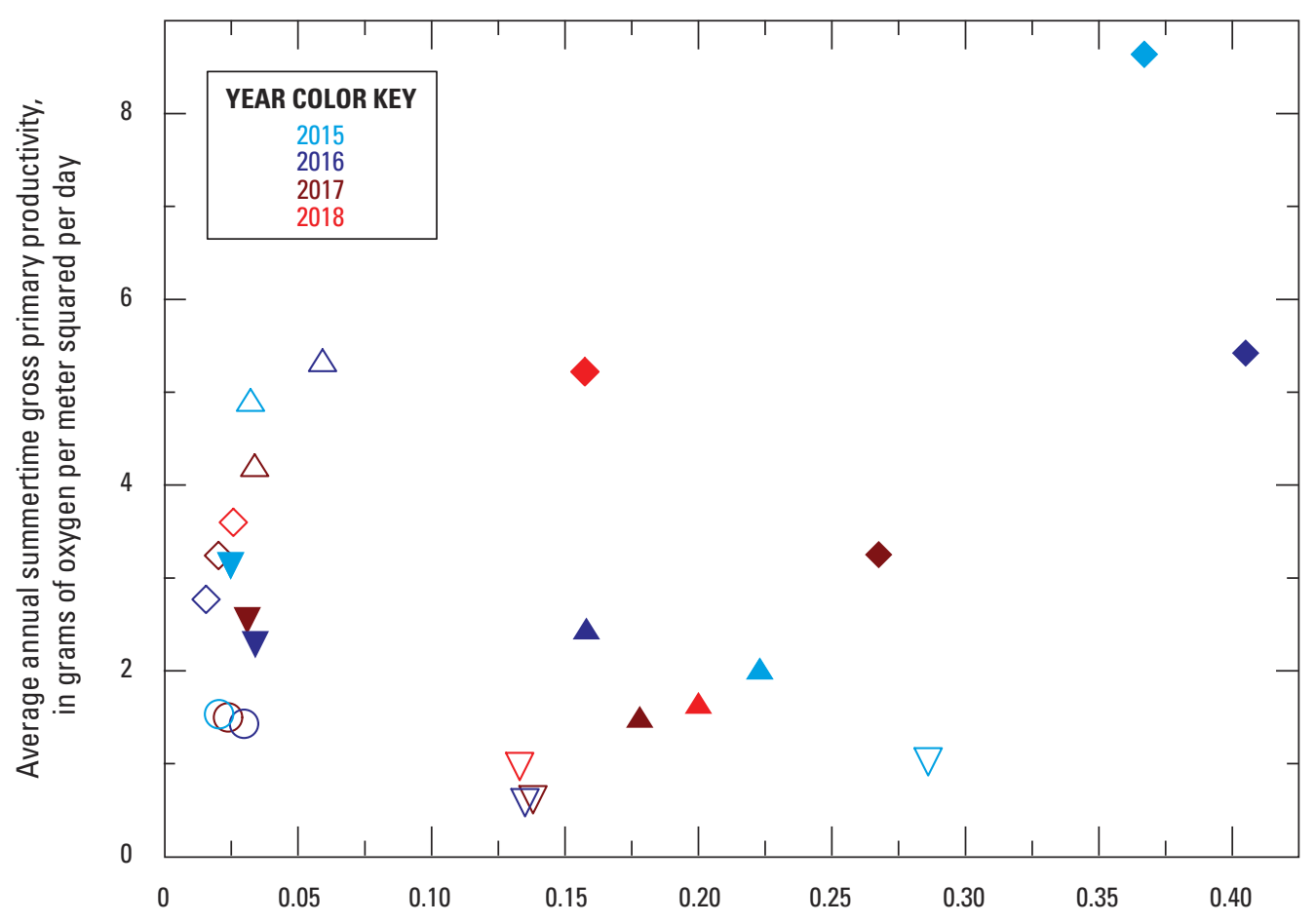

Average annual summertime total phosphorus concentration, in milligrams per liter

\title{
EXPLANATION
}

\author{
Site identifiers \\ $\bigcirc$ Quinebaug River at Quinebaug - U.S. Geological Survey (USGS) station 01124000 \\ $\triangle$ French River at North Grosvenordale-USGS station 01125100 \\ $\diamond$ Salmon River near East Hampton—USGS station 01193500 \\ $\nabla \quad$ Quinnipiac River at Wallingford-USGS station 01196500 \\ $\checkmark \quad$ Norwalk River at South Wilton—USGS station 01209700 \\ - Still River at Route 7 at Brookfield Center-USGS station 01201487 \\ - Naugatuck River at Beacon Falls_USGS station 01208500 \\ V Saugatuck River near Redding —USGS station 01208990
}

Figure 8. Average annual summertime gross primary productivity estimates (in grams of oxygen per meter squared per day) and average annual summertime total phosphorus concentrations (in milligrams per liter) for study sites in Connecticut for June-September. 
not have GPP values as high as Naugatuck River at Beacon Falls even though the two sites recorded daily DO ranges greater than $5 \mathrm{mg} / \mathrm{L}$. Salmon River near East Hampton had TP concentrations lower than $0.05 \mathrm{mg} / \mathrm{L}$ and estimated higher rates of GPP than Still River at Brookfield, which had TP concentrations exceeding $0.15 \mathrm{mg} / \mathrm{L}$. As stated earlier in the report, additional variables including water temperature, streamflow, and canopy cover can affect the relation. The effect of canopy cover can be seen by plotting daily maximum DO against GPP; sites with open canopy tend to group with higher values than sites classified as closed canopy (fig. 9).
Values of K600 were variable from year to year at each site and ranged from a low value of $2.06 \mathrm{gO}_{2} \mathrm{~m}^{-2} \mathrm{~d}^{-1}$ at the Quinnipiac River at Wallingford to a high value of $29.4 \mathrm{~g} 0_{2} \mathrm{~m}^{-2} \mathrm{~d}^{-1}$ at Salmon River near East Hampton. North Branch Park River at Hartford had the most consistent values ranging between 4.15 and $4.78 \mathrm{~g} 0_{2} \mathrm{~m}^{-2} \mathrm{~d}^{-1}$ with an average value of $4.47 \mathrm{~g} 0_{2} \mathrm{~m}^{-2} \mathrm{~d}^{-1}$. The station with the highest variability in K600 values was the Salmon River near East Hampton, which ranged from 16.7 to $29.4 \mathrm{~g} 0 \mathrm{~m}^{-2} \mathrm{~d}^{-1}$ with an average K600 value of $23.8 \mathrm{~g} 0_{2} \mathrm{~m}^{-2} \mathrm{~d}^{-1}$. Coefficients of variation (CVs) were calculated to evaluate confidence in the modeled K600 values (table 3). The CVs ranged from a low of 23.1 at

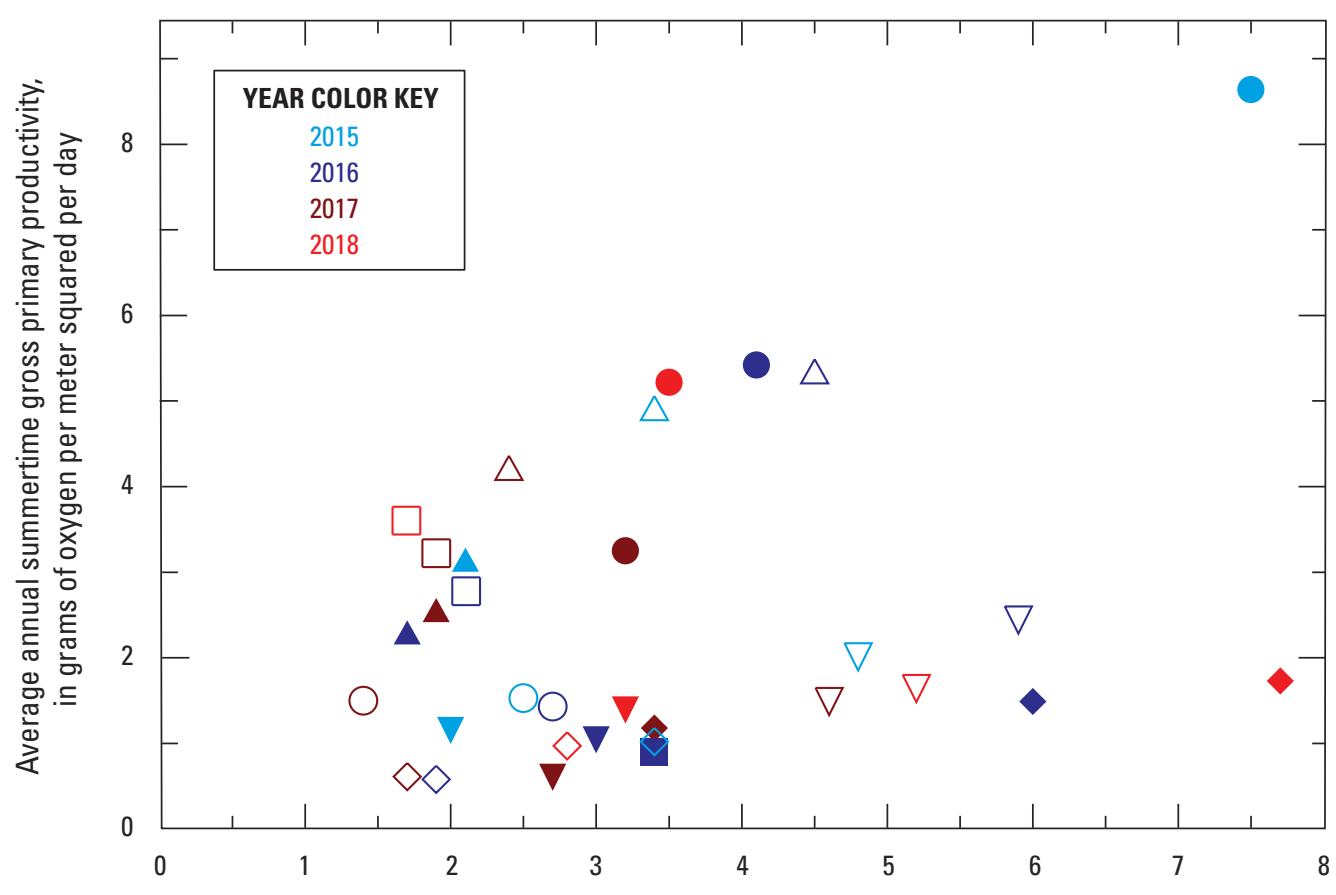

Average annual summertime maximum daily dissolved oxygen range, in milligrams per liter

\section{EXPLANATION}

Figure 9. Average annual summertime gross primary productivity estimates and average annual summertime maximum daily dissolved oxygen ranges for study sites in Connecticut for JuneSeptember. 
Naugatuck River at Beacon Falls to a high of 170 at Quinnipiac River downstream from West Center Street at Southington. K600 values greater than 100 were deemed unrealistic, based on professional judgement, and were truncated to calculate the CVs.

\section{Discussion}

Nutrients are important for sustaining healthy stream ecosystems, but excessive nutrients can negatively affect stream ecosystems and aquatic life. Continuously monitored DO concentrations for this study demonstrated daily diurnal ranges that indicate the relative magnitude of productivity in streams. This information can aid in understanding the effects of nutrient loading on ecological processes in streams. The water quality of streams can change rapidly, and continuous measurements of DO along with other parameters can help characterize these variations. In general, streams in this study are relatively shallow; these lotic systems can experience more gas exchange with the atmosphere compared to deeper or lentic systems. Instream metabolism in lotic systems can vary greatly with differences in channel geomorphology and hydrology, which can make it difficult to extrapolate specific monitoring locations to other parts of the drainage basin watershed (Naiman, 1983). Analysis of diurnal daily DO concentrations, TP concentrations, and stream metabolism at these sites can identify streams strongly affected by phosphorus loading. The continuous DO data combined with biological datasets (that continue to be sampled by CT DEEP) can help determine stream response.

This study identified the dominant land use, stream channel width, velocity, and canopy cover to characterize certain features of stream and riparian habitat. These variables provided a general characterization of the upstream reach at each monitoring location, but a more comprehensive stream assessment in the future would provide a more comprehensive habitat characterization. The one-station method was used for this study to measure metabolic activity of one point in the stream, at the monitoring location. Inferences can be made about the upstream reach of the stream, and a general assessment of the stream reach was made to determine if significant variation existed that would affect the geomorphology. Hydrologic disturbances that alter depth and width and could cause variation in the model assumption about uniform channel geometries were identified and avoided as much as possible. The two-station method, which is based on measurements at an upstream and downstream point, could help incorporate variations in the stream (Bott, 2007), especially if it is known that DO concentration is affected by upstream factors such as groundwater inputs and dams. The additional information would be used to better characterize the stream reach so that more accurate estimates of the $\mathrm{K} 600$ values could be made (Riley and Dodds, 2013). Changes in streamflow can affect water velocities, scour benthic algae, flush phytoplankton algae, and strand parts of the channel in isolated pools or dry them out completely. Variations in streamflow can also change light transmission, which in turn can affect the stream biota response. A more thorough understanding of the changes in streamflow would help in evaluating changes in the DO response within a year and from year to year. Interannual variability in average annual TP concentrations and maximum daily DO concentrations indicated consistencies among some sites and differences among other sites in the years of the study. Reference sites had lower TP concentrations and daily DO concentration ranges. Sites deemed as impaired had higher concentrations of TP, but only Naugatuck River at Beacon Falls and Still River at Brookfield had higher daily DO ranges. Quinnipiac River at Wallingford had higher TP concentrations but lower daily DO ranges throughout the study. The pattern in daily DO ranges and TP concentrations for Naugatuck River at Beacon Falls was particularly notable over the 4-year study. The Waterbury wastewater treatment plant, which discharges into the Naugatuck River upstream from Beacon Falls, had interim reductions in 2015 that consequently have resulted in lower daily DO ranges and TP concentrations.

Heterotrophic and autotrophic states can be essential sources of energy and can be indicated by GPP and ER, respectively. Modeled stream metabolism estimates for this study indicate that most sites are heterotrophic with rates of ER exceeding GPP. Streams receive energy from terrestrial sources (allochthonous) of carbon when they are tightly connected to the landscape and contribute to heterotrophic state. Heterotrophic state can be a function of carbon inputs (leaf debris) and phosphorus supply (wastewater), which fuel the respirations rates. Phosphorus is one of the most important nutrients (along with nitrogen) that stimulate heterotrophic and autotrophic activity. Autotrophic and heterotrophic states can be affected by different factors; light greatly affects the autotrophic state whereas allochthonous carbon input greatly affects heterotrophic state (Dodds, 2007). The balance between GPP and ER can change along a stream depending on previously mentioned variables along the river system (Vannote and others, 1980). Results from this study indicate that rates of metabolism vary greatly in rivers and streams in Connecticut and respond to phosphorus inputs differently. Nutrient concentrations, water temperature, streamflow, canopy cover, and algal community are among the many variables that affect the rate of productivity in streams. Streams that receive a given high concentration of TP may respond differently because of these other variables. A larger stream with open canopy and slower stream velocity could be more productive than a smaller forested stream with faster stream velocity. The high variation of GPP and ER reported for several sites can be affected by many physical, chemical, and biological factors, including the abundance and community composition of phytoplankton, periphyton, and macrophytes present. Better understanding of the relations between phosphorus loading and stream metabolism will require more detailed information of habitat variables (canopy cover, stream velocity, water 
depth), and algal and macrophyte community. This can help to improve the scientific basis for managing phosphorus loading (Dodds and others, 2009).

This study focused on measuring the DO of streams during the summer months and additional information would be needed to assess how metabolic rates of stream ecosystems can vary throughout the year. For smaller streams in forested drainage basins, light availability is greater during the spring when the canopy cover is minimal. Increased light levels could affect the rates of GPP in streams, which ultimately affect the seasonal and diurnal fluctuations in DO concentrations. Thus, additional data during this time would provide a better understanding of the dynamics in the ecosystem and how the streams respond to phosphorus loading during the different seasons (Roberts and others, 2007).

Understanding how GPP and ER can differ between headwater streams and large rivers is important in understanding the effects of nutrient enrichment. The scope of this study was primarily limited to wadable streams and rivers, although evaluating DO and stream metabolism in larger rivers could be a useful additional focus for a future study. Large rivers with slower velocities, longer residence times for nutrient and biotic interactions, deeper water depths, and consistently open canopy cover may result in findings of higher autotrophic activity in these systems. In addition, large river monitoring would help expand the research on phosphorus loading from upland watershed drainage basin loadings to biological responses in larger rivers. Measuring stream metabolism in larger rivers can provide an assessment of how small and large drainage basins react to changing conditions that are related to seasonal, interannual, and anthropogenic variation. Expanding the data collection for these complex river systems can provide a better understanding of the effects from phosphorus loading, which can aid in refining recommendations for nutrient management.

\section{References Cited}

Appling, A.P., Hall, R.O., Jr., Arroita, M., and Yackulic, C.B., 2017, streamMetabolizer-Models for estimating aquatic photosynthesis and respiration: GitHub, Inc., web page, accessed June 2019 at https://github.com/USGS-R/ streamMetabolizer/tree/v0.10.1.

Appling, A.P., Hall, R.O., Jr., Yackulic, C.B., and Arroita, M., 2018a, Overcoming equifinality_Leveraging long time series for stream metabolism estimation: Journal of Geophysical Research. Biogeosciences, v. 123, no. 2, p. 624-645. [Also available at https://doi.org/10.1002/ 2017JG004140.]
Appling, A.P., Read, J.S., Winslow, L.A., Arroita, M., Bernhardt, E.S., Griffiths, N.A., Hall, R.O., Jr., Harvey, J.W., Heffernan, J.B., Stanley, E.H., Stets, E.G., and Yackulic, C.B., 2018b, The metabolic regimes of 356 rivers in the United States: Scientific Data, v. 5, no. 1, art. 180292. [Also available at https://doi.org/10.1038/sdata.2018.292.]

Bales, J.D., and Nardi, M.R., 2007, Automated routines for calculating whole-stream metabolism-Theoretical background and user's guide: U.S. Geological Survey Techniques and Methods, book 4, chap. C2, 33 p. [Also available at https://doi.org/10.3133/tm4C2.]

Becker, E.M., 2014, Interim phosphorus reduction strategy for Connecticut freshwater non-tidal waste-receiving rivers and streams technical support document: Connecticut Department of Energy and Environmental Protection, 70 p. [Also available at https://portal.ct.gov/-/media/DEEP/water/ water_quality_management/monitoringpubs/interimmgntph osstrat042614pdf.pdf.]

Bott, T.L., 2007, Primary productivity and community respiration, chapter 28 of Hauer, F.R., and Lamberti, G.A., eds., Methods in Stream Ecology (2d ed.): New York, Elsevier, p. 663-690.

Carpenter, S.R., Caraco, N.F., Correll, D.L., Howarth, R.W., Sharpley, A.N., and Smith, V.H., 1998, Nonpoint pollution of surface waters with phosphorus and nitrogen: Ecological Applications, v. 8, no. 3, p. 559-568. [Also available at https://doi.org/10.1890/1051-0761(1998)008[0559:NPOS WW]2.0.CO;2.]

Connecticut Academy of Science and Engineering, 2014, Methods to measure phosphorus and make future projections: Rocky Hill, Conn., Connecticut Academy of Science and Engineering, Inc., 66 p.

Connecticut Department of Energy and Environmental Protection [CT DEEP], 2015, Ambient water quality monitoring program strategy, 2015-2024: Hartford, Conn., Connecticut Department of Energy and Environmental Protection, 69 p.

Connecticut Department of Energy and Environmental Protection [CT DEEP], 2019, 2018 Integrated Water Quality Report: Hartford, Conn., Connecticut Department of Energy and Environmental Protection, 57 p., accessed January 2020 at https://portal.ct.gov/-/media/DEEP/water/water_quality_ management/305b/2018CTIntgratedWaterQualityRep ortpdf.pdf.

Connecticut Department of Environmental Protection, 2011, Water quality standards: Hartford, Conn., Connecticut Department of Environmental Protection, 60 p., accessed May 2019 at https://portal.ct.gov/-/media/DEEP/water/ water_quality_standards/wqsfinaladopted22511pdf.pdf. 
Correll, D.L., 1998, The role of phosphorus in the eutrophication of receiving waters-A review: Journal of Environmental Quality, v. 27, no. 2, p. 261-266. [Also available at https://doi.org/10.2134/jeq1998.00472425002 700020004x.]

Dodds, W.K., 2007, Trophic state, eutrophication and nutrient criteria in streams: Trends in Ecology \& Evolution, v. 22 , no. 12 , p. 669-676. [Also available at https://doi.org/ 10.1016/j.tree.2007.07.010.]

Dodds, W.K., Bouska, W.W., Eitzmann, J.L., Pilger, T.J., Pitts, K.L., Riley, A.J., Schloesser, J.T., and Thornbrugh, D.J., 2009, Eutrophication of U.S. freshwaters-Analysis of potential economic damages: Environmental Science \& Technology, v. 43, no. 1, p. 12-19. [Also available at https://doi.org/10.1021/es801217q.]

Dodds, W.K., and Welch, E.B., 2000, Establishing nutrient criteria in streams: Journal of the North American Benthological Society, v. 19, no. 1, p. 186-196. [Also available at https://doi.org/10.2307/1468291.]

Fisher, S.G., and Likens, G.E., 1973, Energy flow in Bear Brook, New Hampshire-An integrative approach to stream ecosystem metabolism: Ecological Monographs, v. 43, no. 4, p. 421-439. [Also available at https://doi.org/ 10.2307/1942301.]

Fishman, M.J., ed., 1993, Methods of analysis by the U.S. Geological Survey National Water Quality LaboratoryDetermination of inorganic and organic constituents in water and fluvial sediments, U.S. Geological Survey OpenFile Report 93-125, 217 p. [Also available at https://doi.org/ 10.3133/ofr93125.]

Fitzpatrick, F.A., Waite, I.R., D'Arconte, P.J., Meador, M.R., Maupin, M.A., and Gurtz, M.E., 1998, Revised methods for characterizing stream habitat in the National Water-Quality Assessment Program: U.S. Geological Survey WaterResources Investigations Report 98-4052, 67 p. [Also available at https://doi.org/10.3133/wri984052.]

Frankforter, J.D., Weyers, H.S., Bales, J.D., Moran, P.W., and Calhoun, D.L., 2010, The relative influence of nutrients and habitat on stream metabolism in agricultural streams: Environmental Monitoring and Assessment, v. 168, p. 461-479. [Also available at https://doi.org/10.1007/ s10661-009-1127-y.]

Hall, R.O., Jr., 2016, Metabolism of streams and rivers, chapter 4 of Jones, J.B. and Stanley E.H., eds., Stream Ecosystems in a Changing Environment: Amsterdam, Elsevier, p. 151-180. [Also available at https://doi.org/ 10.1016/B978-0-12-405890-3.00004-X.]
Holtgrieve, G.W., Schindler, D.E., Branch, T.A., and A'mar, Z.T., 2010, Simultaneous quantification of aquatic ecosystem metabolism and reaeration using a Bayesian statistical model of oxygen dynamics: Limnology and Oceanography, v. 55, no. 3, p. 1047-1063. [Also available at https://doi.org/ 10.4319/lo.2010.55.3.1047.]

Izbicki, B.J., and Morrison, J., 2021, Stream metabolism estimated from dissolved oxygen data in Connecticut streams, 2015-18: U.S. Geological Survey data release, https://doi.org/10.5066/P9HW6IP1.

Naiman, R.J., 1983, The annual pattern and spatial distribution of aquatic oxygen metabolism in boreal forest watersheds: Ecological Monographs, v. 53, no. 1, p. 73-94. [Also available at https://doi.org/10.2307/1942588.]

Odum, H.T., 1956, Primary production in flowing waters: Limnology and Oceanography, v. 1, no. 2, p. 102-117. [Also available at https://doi.org/10.4319/lo.1956.1.2.0102.]

Patton, C.J., and Kryskalla, J.R., 2011, Colorimetric determination of nitrate plus nitrite in water by enzymatic reduction, automated discrete analyzer methods: U.S. Geological Survey Techniques and Methods, book 5, chap. B8, 34 p. [Also available at https://doi.org/10.3133/tm5B8.]

Patton, C.J., and Truitt, E.P., 2000, Methods of analysis by the U.S. Geological Survey National Water Quality Laboratory-Determination of ammonium plus organic nitrogen by a Kjeldahl digestion method and an automated photometric finish that includes digest cleanup by gas diffusion: U.S. Geological Survey Open-File Report 2000-170, 31 p., accessed December 9, 2011, at https://doi.org/ 10.3133/ofr00170.

Riley, A.J., and Dodds, W.K., 2013, Whole-stream metabolism-Strategies for measuring and modeling diel trends of dissolved oxygen: Freshwater Science, v. 32, no. 1, p. 56-69. [Also available at https://doi.org/10.1899/ 12-058.1.]

Roberts, B.J., Mulholland, P.J., and Hill, W.R., 2007, Multiple scales of temporal variability in ecosystem metabolism rates-Results from 2 years of continuous monitoring in a forested headwater stream: Ecosystems (New York, N.Y.), v. 10, no. 4, p. 588-606. [Also available at https://doi.org/ 10.1007/s10021-007-9059-2.]

Rounds, S.A., Wilde, F.D., and Ritz, G.F., 2013, Dissolved oxygen (ver. 3.0): U.S. Geological Survey Techniques of Water-Resources Investigations, book 9, chap. A6.2, 48 p., accessed June 2019 at https://doi.org/10.3133/twri09A6.2.

U.S. Environmental Protection Agency, 2000, National Water Quality Inventory—2000 report: Washington, D.C., U.S. Environmental Protection Agency, 207 p. plus appendixes. 
U.S. Geological Survey, 2008, Field measurements (edited by Wilde, F.D.): U.S. Geological Survey Techniques of Water-Resources Investigations, book 9, chap. A6, accessed April 10, 2015, at https://doi.org/10.3133/twri09A6.

U.S. Geological Survey, 2020, USGS water data for the Nation: U.S. Geological Survey National Water Information System database, accessed February 20, 2020, at

https://doi.org/10.5066/F7P55KJN.

Van Metre, P.C., Riva-Murray, K., and Coles, J.F., 2016, The Northeast Stream Quality Assessment: U.S. Geological Survey Fact Sheet 2016-3021, 2 p. [Also available at https://doi.org/10.3133/fs20163021.]

Vannote, R.L., Minshall, G.W., Cummins, K.W., Sedell, J.R., and Cushing, C.E., 1980, The River Continuum Concept: Canadian Journal of Fisheries and Aquatic Sciences, v. 37, no. 1, p. 130-137. [Also available at https://doi.org/10.1139/ f80-017.]

Wagner, R.J., Boulger, R.W., Jr., Oblinger, C.J., and Smith, B.A., 2006, Guidelines and standard procedures for continuous water-quality monitors-Station operation, record computation, and data reporting: U.S. Geological Survey Techniques and Methods, book 1, chap. D3, 51 p. [Also available at https://doi.org/10.3133/tm1D3.] 

For more information about this report, contact: Director, New England Water Science Center U.S. Geological Survey 10 Bearfoot Road Northborough, MA 01532

dc_nweng@usgs.gov or visit our website at https://www.usgs.gov/centers/new-england-water

Publishing support provided by the Pembroke and Rolla Publishing Service Centers 


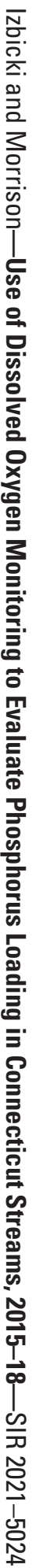

